Prepared for the U.S. Department of Energy

under Contract DE-AC05-76RL01830

\title{
Macroalgae Analysis
}

A National GIS-based Analysis of Macroalgae Production Potential Summary Report and Project Plan
G Roesijadi
KE Buenau
A.M. Coleman
J.D. Tagestad
C. Judd
M.S. Wigmosta
B. Van Cleve
J.A. Ward
R.M. Thom

December 2011

Pacific Northwest

NATIONAL LABORATORY

Proudly Operated by Battelle Since 1965 




\title{
DISCLAIMER
}

This report was prepared as an account of work sponsored by an agency of the United States Government. Neither the United States Government nor any agency thereof, nor Battelle Memorial Institute, nor any of their employees, makes any warranty, express or implied, or assumes any legal liability or responsibility for the accuracy, completeness, or usefulness of any information, apparatus, product, or process diselosed, or represents that its use would not infringe privately owned rights. Reference herein to any specific commercial product, process, or service by trade name, trademark, manufacturer, or otherwise does not necessarily constitute or imply its endorsement, recommendation, or favoring by the United States Government or any agency thereof, or Battelle Memorial Institute. The views and opinions of authors expressed herein do not necessarily state or reflect those of the United States Government or any agency thereof.

\author{
PACIFIC NORTHWEST NATIONAL LABORATORY \\ operated by \\ BATTELLE \\ for the \\ UNITED STATES DEPARTMENT OF ENERGY \\ under Contract DE-AC05-76RL01830 \\ Printed in the United States of America \\ Available to DOE and DOE contractors from the \\ Office of Scientific and Technical Information, \\ P.O. Box 62, Oak Ridge, TN 37831-0062; \\ ph: (865) 576-8401 \\ fax: (865) $576-5728$ \\ email: reports@adonis.osti.gov

\begin{abstract}
Available to the public from the National Technical Information Service, U.S. Department of Commerce, 5285 Port Royal Rd., Springfield, VA 22161 ph: (800) 553-6847 fax: $(703) 605-6900$

email: orders@ntis.fedworld.gov

online ordering: http://www.ntis.gov/ordering.htm
\end{abstract}

This document was printed on recycled paper.

(9/2003) 


\section{Macroalgae Analysis}

\section{A National GIS-based Analysis of Macroalgae Production Potential Summary Report and Project Plan}
G Roesijadi
A.M. Coleman
C. Judd
B. Van Cleve
Buenau, K.E.
R.M. Thom
Ward, J.A.
M.S. Wigmosta

December 2011

Prepared for

the U.S. Department of Energy

under Contract DE-AC05-76RL01830

Pacific Northwest National Laboratory

Richland, Washington 99352 


\section{Abstract}

The DOE-OBP Multi-year Program Plan (MYPP) biomass production targets are 44 million dry tons per year by 2012 and 155 million dry tons per year by 2017 (EERE Biomass Program, 2011). Macroalgae, more commonly known as seaweed, could be a significant biomass resource for the production of biofuels. The overall project objective is to conduct a strategic analysis to assess the state of macroalgae as a feedstock for biofuels production. To this end, this project provides an assessment of the potential for domestic macroalgae production and identifies the key technical issues associated with the feasibility of using macroalgae resources. Work began in FY10 as a screening analysis of the key questions related to the status of macroalgae as a feedstock resource. These efforts addressed the state of technology, types of fuels possible, a rough order-of-magnitude resource assessment, and preliminary high-level economic analysis, resulting in a Summary Report entitled Macroalgae as a Biomass Feedstock: A Preliminary Analysis (PNNL-19944).

While considerable progress has been made in developing and applying GIS-based spatiotemporal models of high granularity to siting microalgal growth facilities in terrestrial landscapes in the continental U.S. (Wigmosta et al., 2011), parallel efforts to identify suitable sites for macroalgal cultivation in U.S. marine waters have yet to be reported. Such effort requires development of new analysis tools because those developed for land-based microalgal resources (Wigmosta et al., 2011) are not directly applicable to marine waters. Thus, the plan for subsequent years, starting in FY11, was to develop a multi-year systematic national assessment to evaluate the U.S. potential for macroalgae production using a GISbased assessment tool and biophysical growth model developed as part of these activities. The broad goal of this modeling effort is to develop a National Macroalgae Assessment Model for evaluating macroalgae production in marine waters within the U.S. Exclusive Economic Zone (EEZ). Focus was placed on an assessment of kelp, a group of brown macroalgae considered suitable for conversion to biofuels based on biochemical composition and growth characteristics. Progress in FY11, which focused on model development and initial application of the models to demonstration areas in offshore waters, is described in this report.

During FY11, a concept map describing spatial models to identify suitable sites for producing macroalgae biomass was developed as a framework for conducting a GIS-based national resource assessment within the U.S. EEZ. The spatial models included modeling macroalgae production potential, constrained by competing uses and legal, environmental, and infrastructure considerations at specified locations in the U.S. EEZ. A literature review of these constraints was conducted, and remotely-sensed data sources were identified, downloaded, and processed using 8-day composites from 2000 to 2011 to support site screening and macroalgae growth model development. Model demonstration areas off the Pacific and Atlantic coasts of the United States were identified, and efforts were directed to modeling constraints and production potential within these regions. The overall resource model, conceived as a merged model, consists of a biomass production model (the Macroalgae Growth Model) constrained by conflicting uses of marine waters under U.S. jurisdiction (the Constraints Model). Areas with high constraints are eliminated for further consideration as production sites. This report includes the initial model development and initial application of models to demonstration areas in the U.S. EEZ.

Legal, environmental, and competing use constraints were analyzed and used to construct maps of overall constraints within the demonstration areas. Areas of low, moderate, and high constraints were identified in both of the demonstration areas, with the last identifying locations not advised for macroalgal 
cultivation. The analysis showed that there are fewer conflicts farther from shore. There are also different barriers in different regions. For example, with respect to the demonstration areas, there are greater competing use conflicts in Southern California than in Gulf of Maine. For the physics-based resource assessment, spatiotemporal evaluation of sea surface temperature and photosynthetically-active radiation were used to develop suitability maps for kelp viability for the East and West Coasts of the United States. These showed extensive areas where environmental conditions could sustain populations of macroalgae. Application of a macroalgae growth model developed in this study to the West Coast demonstration area off Southern California showed that warmer water temperatures in the southern portion would impede growth and result in lower overall production of biomass. A plan to merge the results of the constraints and growth models to construct an initial composite assessment has been developed and would be applied in future work, which is contingent on future interest and needs of the Biomass Program. It would include completion of modeling the demonstration areas and expansion to a national assessment that covers the entire U.S. EEZ off the North American continent.

Also conducted were an assessment of infrastructure needs for offshore cultivation based on published and grey literature and an analysis of the type of local, state, and federal requirements that pertain to permitting land-based facilities and nearshore/offshore culture operations. Infrastructure needs include facilities for onshore cultivation and rearing, offshore deployment and rearing, harvesting, and processing. Multiple federal, state, and local laws regulate development and industrial activities on land and in the marine environment. Locating marine aquaculture to offshore sites in the U.S. EEZ would shift the regulatory burden in marine waters to federal agencies. Major information gaps and challenges encountered during this analysis were identified. 


\section{Table of Contents}

Abstract

Table of Contents

List of Tables

List of Figures

II. SCIENCE-BASED GIS MACROALGAE RESOURCE ASSESSMENT

II.a. General Background

II.b. The Selection Constraints Model for Siting Production Activities

II.b.1. Background

II.b.2. Review of Existing Methods

II.b.2.1. Approaches from Aquaculture and Renewable Energy Siting

II.b.2.2. Selection Constraints

II.b.2.3. Assessment Approaches to Ranking Constraints

II.b.2.4. Considerations for a National Macroalgae Assessment

II.b.3. Conceptual Model for Marine Use and Conflicts

II.b.3.1.Conceptual Model Creation

II.b.4. Geospatial Model Development and Application to Study Sites___ 8

$\begin{array}{ll}\text { II.b.4.1. Geospatial Analysis__ } & 8\end{array}$

$\begin{array}{ll}\text { II.b.4.2. View Assessment Analysis___ } & 12\end{array}$

II.b.4.3. Modifications to Ranking__ 13

II.b.4.4. Results for Applying Selection Constraints Model to Demonstration Areas___ 13

II.b.5. Assessment of Uncertainty___ 19

$\begin{array}{ll}\text { II.b.5.1. Score Sensitivity___ } & 19\end{array}$

$\begin{array}{ll}\text { II.b.5.2. Project Comparison___ } 19 & 19\end{array}$

$\begin{array}{ll}\text { II.b.6. Future Plans } & 19\end{array}$

II.c. The Biophysical Growth Model For Siting Production Activities - A GIS-Based Resource Assessment_20

II.c.1. Background _ 20

II.c.2. Spatiotemporal Analysis of Biophysical Conditions__ 23

II.c.2.1. Sea Surface Temperature___ 24

II.c.2.2. Photosynthetically Active Radiation__ 27

II.c.3. Macroalgae Growth Model___ 28

II.c.3.1. Growth Model__ 28

II.c.3.2. Preliminary Results__ 29

II.c.4. Future Macroalgae Growth Model Enhancements___ 30

II.d. Merged Macroalgae Resource Model for optimal production and mitigation of competing uses 31

III. BIOFUELS INFRASTRUCTURE NEEDS AND INFORMATION GAPS_ 33

III.a. Background 33 
III.b. Cultivation Site Location

III.c. Macroalgae Production

III.d. Infrastructure Associated with Phases of Development

III.e. Cultivation of Seeds and Rearing of Plantlets

III.f. Transportation to Offshore Growing Site

III.g. Offshore Deployment

III.h. Harvest

38

III.i. Transportation to Shore 38

III.j. Preprocessing 39

III.k. Land Transportation, Final Processing, Packing, and Distribution 39

III.1. Information Gaps and Challenges

IV. PERMITTING REQUIREMENTS FOR MARINE BIOFUELS PRODUCTION

IV.a. Background 41

IV.b. National Aquaculture Policy 41

IV.c. Permitting Requirements for Offshore Macroalgal Production 42

V. SUMMARY 48

VI. FUTURE PROJECT RECOMMENDATIONS 50

Relevance to Program Goals 50

VII. REFERENCES

VIII. APPENDIX A

Summary of State and Local Authorizations for California, Maine, and Massachusetts 54 


\section{List of Tables}

Table 1. Literature Review of Constraints from Aquaculture and Renewable Energy Siting Studies.__ 6

Table 2a. Geospatial Analysis Component: Legal Constraints. _ 9

Table 2b. Geospatial Analysis Component: Environmental Constraints.___ 10

Table 2c. Geospatial Analysis Component: Competing Use Constraints.___ 11

Table 3. Visual acuity metrics based on distance of an $8 \mathrm{~m}$ x $500 \mathrm{~m}$ structure from shoreline.___ 12

Table 4. Constraint level classification in study areas. In state waters, most areas are classified as having a "High" constraint level.__ 13

Table 5. Offshore Algae Culture Experience.__ 37

Table 6. Federal authorities governing offshore macroalgal aquaculture.___ 46

\section{Appendix Tables}

Table A. Summary of California Authorizations including federal authorizations delegated to states (Pacific Energy Ventures, 2010).

Table B. Summary of Maine Authorizations including federal authorizations delegated to states (Pacific Energy Ventures, 2010).

Table C. Summary of Massachusetts Authorizations including federal authorizations delegated to states (Pacific Energy Ventures, 2010). 


\section{List of Figures}

Figure 1. Hierarchical Model Relating Selection Factors to Selection Constraints (Malczewski, 1999). 3

Figure 2. Demonstration areas are bounded by the red rectangles off Southern California and New

England. They include coastal waters off Southern California to the western boundary of the U.S.

EEZ and the Gulf of Maine to the eastern boundary of the U.S. EEZ. Gray boxes within the demonstration areas represent the relative size of a preliminary estimate of $\sim 11,000 \mathrm{~km}^{2}$ needed to meet nominal $1 \%$ of U.S. gasoline consumption (Roesijadi et al., 2010).

Figure 3. Legal Jurisdiction in marine waters often depends on the distance from shore. State agencies have regulatory jurisdiction in many cases within 3 nautical miles from the coastline.

Figure 4. Visualization of potential macroalgae cultivation structures. Floating macroalgae facility dimensions were $500 \mathrm{~m} \times 500 \mathrm{~m}$ in size with a height of $8 \mathrm{~m}$. These were mapped 1 mile, 2 miles, and 3 miles offshore from an observation point on shore.

Figure 5. A rule-based decision tree for classification each cell within study area was used to create final classification for each constraint theme, as well as an overall constraint level for each site.

Figure 6. Legal Constraints. Evaluation examined MPA (upper left), Military Use (upper right), and State Marine Zone (lower left). Final Evaluation Map (lower right) used a decision tree to define the level of legal constraint within each $250 \mathrm{~m}$ cell within the study area. Legend: Low - light green; Moderate - yellow; High - Red; Exclusion - black. Demonstration areas are identified by green circles.

Figure 7. Environmental Constraints. Mapped constraint areas (left) with final environmental constraint level (right). Legend for mapped constraints: Habitat Areas of Particular Concerns (HAPC) - red; Cultural Heritage - orange; Essential Fish Habitat (EFH)-Conservation Area - mauve; Essential Fish Habitat (EFH)-Fishing Restrictions - light blue. Legend for constraint level: Low - tan; Medium yellow; High - red. Demonstration areas are identified by green circles.

Figure 8. Competing Use Constraints. Cables and navigation (upper left), recreation use (upper right) and visual acuity assessment (lower left). Legend for Cables and navigation: Platforms - light blue; Pipes - aquamarine; Cables - mauve; Shipping - light orange. Legend for recreation use: High green. Legend for visual acuity: None - green; Low - pink; Intermediate - orange; high - Red. Demonstration areas are identified by green circles.

Figure 9. Final constraint level for study areas. Legend for constraint level: High - orange; Moderateyellow; Low - light green. Areas not shaded have a null constraint level.

Figure 10. California Ocean Uses Atlas for Recreation Use. The recreation use assessment used in this assessment had slightly higher scores than the Ocean Uses Atlas.

Figure 11. Framework for the Macroalgae Growth Model and the limits imposed by constraints derived from conflicting uses and infrastructure needs described in the previous section. The latter would limit areas considered suitable for siting cultivation activities.

Figure 12. The growth rate of macroalgae is defined by a complex relationship between light availability, water temperature, and nutrient availability. SST is Sea Surface Temperature.

Figure 13. Sea surface temperature and chlorophyll concentration off the coast of Southern California. For SST, locations of coastal upwellings are shown. Chlorophyll concentrations are presented as monthly means during the period 1997-2006.

Figure 14. Relationship between wave and current characteristics and removal of kelp from attachments due to excess drag force. Thresholds represent the upper limit of conditions that enable viability of kelp.

Figure 15. Dynamic relationships stemming from solar insolation and sea surface temperature (SST). A) Processes affected by energy flow from solar insolation. B) Changes in SST as a function of wind speed and time of day. 
Figure 16. Spatiotemporal temperature evaluation within the EEZ. Maps were built from 8-day composites for a ten-year period from 2001 through 2010 and are shown for the months of January and August. High-temperature values near the shoreline do not accurately reflect sea surface temperature values due to combined land and sea surface temperature within a given $4 \mathrm{~km}$ pixel. Datasets were obtained from MODIS Terra SST (MOD 24).

Figure 17. General suitability maps for kelp growth as a function of temperature in the U.S. EEZ off the East and West Coasts of the United States using temperature suitability rules. Maps are shown for months of January to December (top left to bottom right). Legend: Not Suitable - White; Low Suitability - orange; Medium Suitability - aquamarine; High Suitability - Green.

Figure 18. Spatiotemporal PAR evaluation within the EEZ. Shown are maps depicting 10-year mean monthly PAR for January and February built from 8t-day composites from 2001-2010.

Figure 19. Suitability map for kelp growth as a function of Photosynthetically Active Radiation in the U.S. EEZ off the East and West Coasts of the United. States. This example shows the composite suitability for December 2001-2010 using PAR suitability rules.

Figure 20. Subsurface Light Angle. The refraction of light as it moves from air to water.

Figure 21. Application of the Macroalgae Growth Model to the West Coast Demonstration Area off the coast of Southern California to the western and southern limits of the EEZ. A) Mean monthly temperature and PAR measurements over the period 2001-2010. The effect of available PAR at the water surface and at a $6 \mathrm{~m}$ depth is illustrated and clearly indicates that light saturation limits are not achieved at this depth. B) Spatial data results of relative growth rates in the West Coast Demonstration Area off Southern California, where values of 1 are areas of lowest growth rates, and 8 are the highest. Warmer water temperatures in the southern portion of the study site are impeding growth and reporting lower overall biomass.

Figure 22. Spatial analysis of macroalgal production potential and conflicting use constraints.

Figure 23. Marine biofuels infrastructure requirements for commercial production.

Figure 24. Summarized view of consenting agencies by major issue area for projects in federal versus state waters. The hashed blue line represents the limit of state waters (generally 3 nautical miles offshore). Federal agencies straddling the hashed line have consenting authority in both federal and state waters. 


\section{INTRODUCTION}

Meeting the goals of the Energy Independence and Security Act of 2007 (EISA) for advanced biofuels requires development of a large sustainable supply of diverse biomass feedstocks from across the country. The DOE-OBP Multi-year Program Plan (MYPP) biomass production targets are 44 million dry tons per year by 2012 and 155 million dry tons per year by 2017 (EERE Biomass Program, 2011). The amounts of marine biomass, i.e., macroalgae, that could be available as feedstock are potentially very high, exceeding the biomass potential for terrestrial feedstocks, according to a recent study (Chynoweth et al., 2001). Marine biomass is a potential contributor to EISA and MYPP goals, but very little analysis has been done on domestic production as a biomass feedstock for biofuels.

There is already a worldwide market for macroalgae to supply the food and hydrocolloid industries, which is being met by foreign producers. Worldwide commercial production of macroalgae is mainly the result of cultivation through aquaculture in Asia, with less than $10 \%$ contributed by harvest of natural populations. The U.S. does not produce macroalgae at the scale needed to meet feedstock needs for a biofuels industry. Domestic growers of seaweed currently supply specialty markets for food and natural products derived from seaweed. Harvesting natural populations in the United States is highly regulated by individual states for environmental sustainability and conservation. Overall, the U.S. contributes only marginally to the world production of cultivated macroalgae and is not listed as a producer by United Nations Food and Agricultural Organization (FAO) (FAO, 2008). A major expansion of the macroalgae cultivation industry would need to take place for the U.S. to grow sufficient quantities to supply the feedstock needs for biofuels. Domestic production of macroalgae would likely occur in marine waters and would not compete with existing land-based energy crops for land or use of freshwater.

There is a need to assess the production potential of macroalgae cultivation in U.S. waters if macroalgae are to be considered a feedstock to contribute to national biomass targets. Such an analysis has yet to be conducted for marine waters of the U.S. Thus, our Macroalgae Analysis Project represents an initial attempt to provide such an assessment. Year 1 of the Macroalgae Analysis project (FY10) focused on a preliminary feasibility analysis of macroalgae as a biomass feedstock for biofuels production (Roesijadi et al., 2010). The goal for FY11 and remaining out-years of the project focuses on resource assessment and strategic analysis of U.S. macroalgae production as a feedstock resource. This effort requires development of new analysis tools because those developed for land-based microalgal resources (Wigmosta et al., 2011) are not directly applicable to marine waters. The development of this resource assessment and analysis tool suite would expand current capabilities in assessing national biomass potential to include a new resource.

In FY11, we defined and developed spatial models for suitable environmental conditions for biomass production by selected macroalgae species. The resulting information was used as input to an early development macroalgae growth model. Based on these results, a detailed evaluation included the necessary data requirements and available data sources. A determination was made regarding availability of required data, important data gaps, and strategies for addressing data gaps through modeling or other parameter estimation methods. This plan was accelerated to include preliminary application of the model to demonstration areas in the U.S. Exclusive Economic Zone (EEZ)—federal waters usually between 3 and 200 miles offshore- for reasons discussed below.

Moreover, the establishment of a de novo macroalgae biomass production industry in the U.S. could conflict with other uses of marine waters associated with commercial, recreational, military activities, and marine preserves. Legal and environmental restrictions could also serve as constraints on siting cultivation activities in marine waters. Thus, the assessment also included conflicting uses and other constraints that could serve as limiting factors in areas considered suitable for growth of macroalgae. 
Options for locating production sites include land-based ponds, nearshore farming, and offshore farming out of the jurisdiction of local and state regulatory oversight (Roesijadi et al., 2010). Of these, the scale needed for production and the limits on use of nearshore coastal sites suggests that offshore siting should be a primary consideration. For locating marine aquaculture activities in the U.S., The Pew Oceans Commission observed that the U.S. EEZ has the advantages of access to improved water quality, limited conflict from coastal landowners and other users, and independence from state regulations (Pew Oceans Commission, 2003). Thus, we use cultivation in offshore waters in the EEZ as the base-case for a resource assessment and analysis of conflicting uses for siting macroalgae cultivation sites. Other considerations include coastal infrastructure and permitting requirements, and these are also addressed in this report. 


\section{SCIENCE-BASED GIS MACROALGAE RESOURCE ASSESSMENT}

\section{II.a. General Background}

GIS-based analyses have been used to identify the best location for aquaculture and renewable energy facilities to maximize production and minimize conflicts (Nath et al., 2000; Kapetsky and AguilarManjarrez, 2007). Common to resource assessments is that each includes an assessment of site suitability, and most consider site constraints or conflicts for use of that space (Nath et al., 2000; Salam, 2003; Longdill et al., 2008).

Spatial multicriteria decision analysis (MCDA) (Malczewski, 1999), is used to examine and weigh multiple considerations over a study area, identifying those that maximize or optimize criteria. When criteria focus on differences in attributes of the area (multi-attribute decision making), the approach can be viewed as a simple hierarchical model that evaluates criteria for selection with use of submodels that are, in turn, used to prioritize the best areas for aquaculture activities (Figure 1).

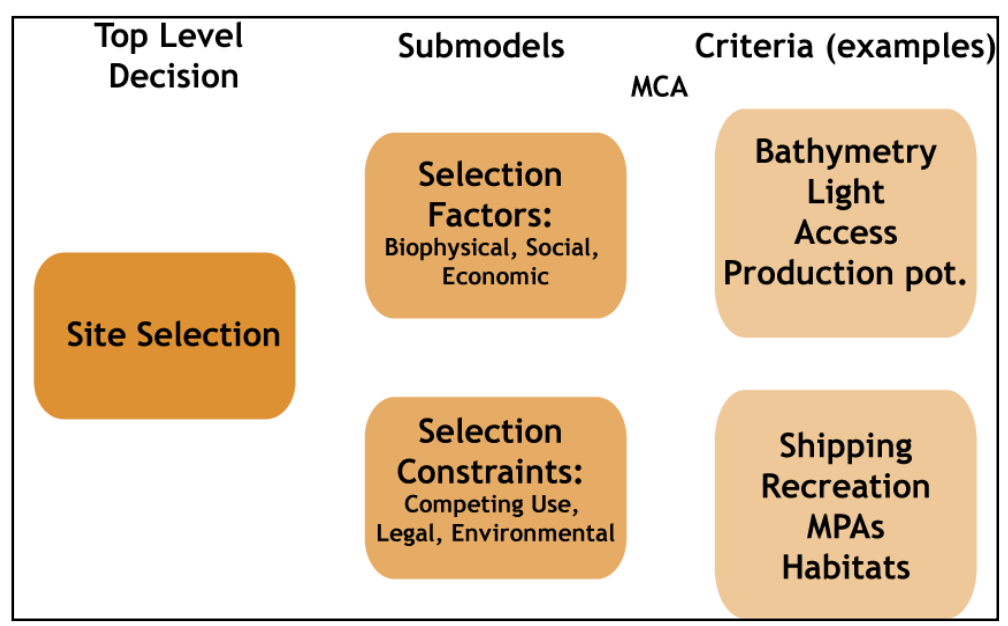

\section{Figure 1. Hierarchical Model Relating Selection Factors to Selection Constraints} (Malczewski, 1999).

Two types of submodels, designated 1) Selection Factors and 2) Selection Constraints, are generally used in most assessments. "Selection Factors" refers to criteria that make a site more or less desirable based on the potential for the site to produce. This may include a biophysical assessment of site, assessment of potential productivity or a social-infrastructure assessment. "Selection Constraints" are those criteria that may make an otherwise suitable site undesirable for development. For example, there may be explicit regulations forbidding aquaculture development. There may also be extensive competition for use of limited space (e.g., recreation, commercial fishing, or other activity).

Our approach in utilizing the submodels is to first consider Selection Constraints because constraints such as competing uses and regulatory matters may eliminate areas from further consideration, the quality of the area for production notwithstanding. Once areas are deemed suitable due to the low impact of constraints, those areas can be considered for further suitability of the Selection Factors. This approach reduces the effort involved in modeling areas for suitability of the chemical, physical, and biological 
features needed to support macroalgal growth and production by establishing a priori those areas where societal constraints would and would not restrict siting.

Two demonstration areas, off Southern California and in the Gulf of Maine (Figure 2), were selected for geospatial model development and initial application of the models. They represent potential areas of high kelp growth and multiple and varied competing uses. Area studies extended out to the EEZ boundaries. Following the initial application of models to the demonstration areas, subsequent work is planned to extend out to the entire U.S. EEZ contiguous to the East and West coasts of the continental U.S.

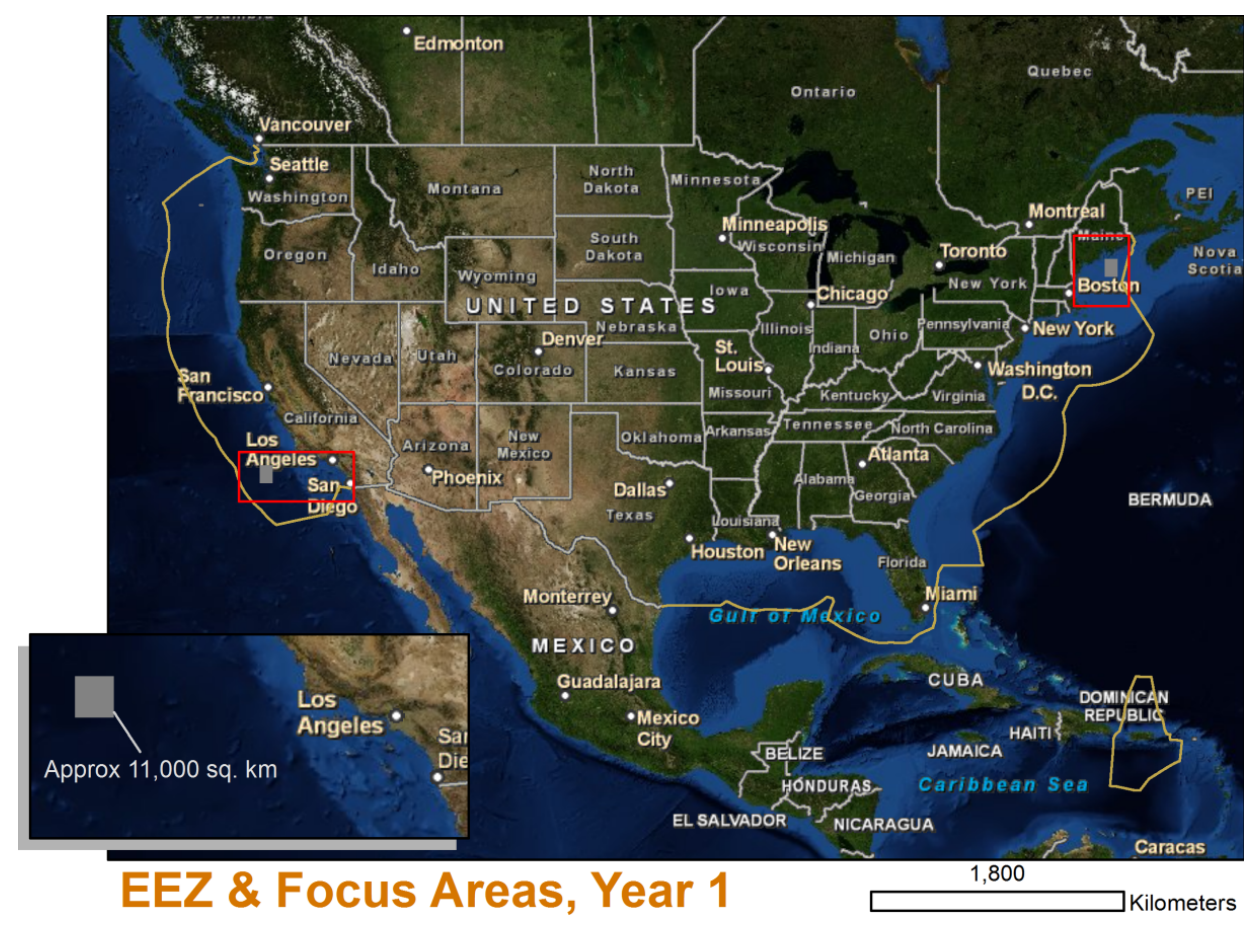

Figure 2. Demonstration areas are bounded by the red rectangles off Southern California and New England. They include coastal waters off Southern California to the western boundary of the U.S. EEZ and the Gulf of Maine to the eastern boundary of the U.S. EEZ. Gray boxes within the demonstration areas represent the relative size of a preliminary estimate of $\sim 11,000 \mathrm{~km}^{2}$ needed to meet nominal 1\% of U.S. gasoline consumption (Roesijadi et al., 2010).

\section{II.b. The Selection Constraints Model for Siting Production ACtivities.}

\section{II.b.1 Background}

Marine algal cultivation may provide an alternative energy source for the nation, and the largely undeveloped U.S. EEZ, which extends 200 nautical miles from the U.S. coastline, provides a large area for potential production. Because there are existing activities and societal considerations, it is not feasible to construct a marine algal cultivation facility in all areas with high potential growth rates. Resource production figures would need to be tempered with realistic projections based on economic feasibility (Would it cost too much?), legal and structural feasibility (Can a structure be built and operated in area?), and social and environmental considerations (What would the public and interest groups think?). 
The objective of this task is to develop a methodology to be used in a nationwide spatial assessment of potential barriers or restrictions on development of marine biomass production for biofuels, and in this year, apply and refine an approach for marine use conflicts at two study sites in the US.

To accomplish this, we (1) conducted a literature review of existing methods for coastal assessment of competing uses, (2) developed a conceptual model for marine use and conflicts, and (3) developed a geospatial model and applied the model to two study sites. We also worked on assessing uncertainty in model parameters and results distribution.

\section{II.b.2. Review of Existing Methods}

The renewable energy sector experienced tremendous growth and investment over the past five years, primarily with land-based renewable systems. Approaches to identify priority areas for resource development of land-based systems are developing. Recently there has been increased interest in assessing the potential and limitations for renewable energy options in the territorial waters off the U.S. coast, primarily with offshore wind systems. However, macroalgal production is neither entirely like landbased renewable energy, nor is it completely the same as traditional aquaculture.

Marine projects are subject to unique opportunities and constraints not seen on land-based systems. First, the marine environment is very dynamic. Offshore structures are exposed to varying environmental conditions caused by storms and ocean currents, resulting in wave forces, and varying salinity, nutrient, water temperature, and turbidity conditions. Production rates may not always be stable, and even the growth structure itself can be exposed to damaging conditions. The producer has little control over these dynamic conditions; however, analysis of long-term environmental conditions can minimize the risk and optimize to areas of highest growth. Second, laws and regulations are complex in marine systems and there can be many entities interested in utilizing the same area. This "use" may be as simple as a view provided to a tourist or resident, to competition for use of the same port facilities, or use of a potential area for recreation, industry, or military activities. Finally, operating offshore facilities can lead to significant expenses, both with the initial construction, as well as access, maintenance, and transport.

II.b.2.1. Approaches from Aquaculture and Renewable Energy Siting. Two bodies of literature were reviewed, those dealing with siting of aquaculture facilities and those with renewable energy facilities. In questions dealing with marine transport, access, and agency use restrictions, aquaculture facilities would be more similar to macroalgal production. In terms of the scale of the project, concerns with environmental conflicts and conflicts with public uses likely would be more similar to renewable energy siting.

II.b.2.2. Selection Constraints. A review of assessments found a range of constraints (Table 1), which can be broadly placed into four categories:

1) Access Constraints - Access constraints or logistic constraints refer to the ease of use of a potential site. Distance to port facility, distance to land-based facilities and remoteness of town are some concerns when evaluating how accessible a site is.

2) Legal Constraints - Legal constraints are where existing laws limit or prohibit aquaculture activities

3) Environmental Constraints - Environmental constraints are conflicts due to existing habitats for protected species, migration or movement corridors or culturally valued habitats or species. 
4) Competing Use Constraints - Competing uses are when current or planned use may conflict with aquaculture production.

\begin{tabular}{|c|c|c|c|c|c|c|c|c|c|}
\hline & \multicolumn{7}{|c|}{ Aquaculture } & \multicolumn{2}{|c|}{$\begin{array}{c}\text { Renewable } \\
\text { Energy }\end{array}$} \\
\hline Conflicting Use & 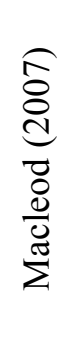 & 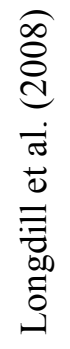 & 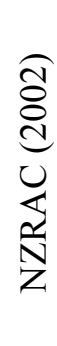 & 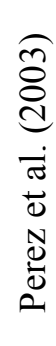 & 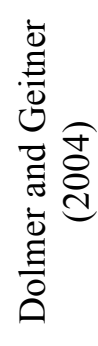 & 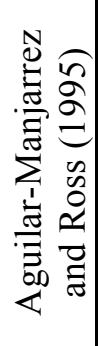 & 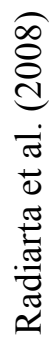 & 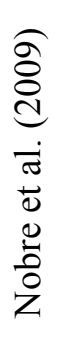 & 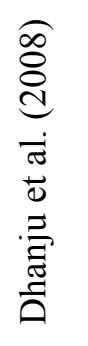 \\
\hline
\end{tabular}

\begin{tabular}{|l|l|l|l|l|l|l|l|l|l|}
\hline Access Constraints \\
\hline Distance to Town & & & & & & & $\mathrm{X}$ & $\mathrm{X}$ & \\
\hline Distance to Piers & & & & & & & $\mathrm{X}$ & & \\
\hline Distance to Land-based Facilities & & & & & & & $\mathrm{X}$ & $\mathrm{X}$ & \\
\hline
\end{tabular}

\begin{tabular}{|l|c|c|c|c|c|c|c|c|c|}
\hline Legal Constraints & $\mathrm{X}$ & & $\mathrm{X}$ & & & & & $\mathrm{X}$ & $\mathrm{X}$ \\
\hline Military Zones & $\mathrm{X}$ & $\mathrm{X}$ & & & $\mathrm{X}$ & $\mathrm{X}$ & & $\mathrm{X}$ & \\
\hline Conservation Zones & & $\mathrm{X}$ & & & & & & & \\
\hline Other Legal Constraints & & & & \\
\hline
\end{tabular}

\begin{tabular}{|l|l|l|l|l|l|l|l|l|l|}
\hline Environmental Constraints \\
\hline Long term monitoring areas & & & & & $\mathrm{X}$ & & & & \\
\hline Critical Habitats & & $\mathrm{X}$ & $\mathrm{X}$ & $\mathrm{X}$ & $\mathrm{X}$ & & & & \\
\hline Cultural and Traditional Use Sites & & $\mathrm{X}$ & $\mathrm{X}$ & & & & & & \\
\hline Restoration Areas & & & & & & & & & $\mathrm{X}$ \\
\hline Con
\end{tabular}

\begin{tabular}{|l|c|c|c|c|c|c|c|c|c|}
\hline Competing Use Constraints & $\mathrm{X}$ & $\mathrm{X}$ & & & $\mathrm{X}$ & & & $\mathrm{X}$ & $\mathrm{X}$ \\
\hline Shipping/Navigation & $\mathrm{X}$ & & $\mathrm{X}$ & $\mathrm{X}$ & $\mathrm{X}$ & & & $\mathrm{X}$ & \\
\hline Oil Platforms, Cables \& Pipes & $\mathrm{X}$ & & & & $\mathrm{X}$ & & & & $\mathrm{X}$ \\
\hline Dredge Disposal Areas & & & & & & & & & $\mathrm{X}$ \\
\hline Chemical and Weapons Disposal & $\mathrm{X}$ & $\mathrm{X}$ & & & $\mathrm{X}$ & & & & \\
\hline Commercial Fishing & $\mathrm{X}$ & $\mathrm{X}$ & $\mathrm{X}$ & $\mathrm{X}$ & $\mathrm{X}$ & & & & \\
\hline Recreation/Tourist Conflicts & $\mathrm{X}$ & & $\mathrm{X}$ & & & & & & \\
\hline Sand, Gravel, Mineral Extraction & $\mathrm{X}$ & $\mathrm{X}$ & & $\mathrm{X}$ & & & & & $\mathrm{X}$ \\
\hline View & & & $\mathrm{X}$ & $\mathrm{X}$ & $\mathrm{X}$ & & $\mathrm{X}$ & & \\
\hline Port Facilities & & & $\mathrm{X}$ & & & & & & \\
\hline Ship Wrecks & & & & & & \\
\hline
\end{tabular}


However, there are additional constraints to consider. For example, in addition to factors above, Macleod (2007) considers engineering constraints.

II.b.2.3. Assessment Approaches to Ranking Constraints. Studies that used multiple criteria used a form of MCDA in their assessments. However, those studies differ in their ranking and weighting approaches to constraining criteria. Salam et al. (2003) uses only Boolean values for constraining criteria. Kapetsky and Aguilar-Manjarrez (2007) point to the example of the New Zealand Regional Council (2002), which further divides constraint assessment into (a) absolutely constrained, (b) limited opportunity and (c) opportunity. Other studies have used pairwise comparison to rank constraints relative to one another. Finally, fuzzy models have been used for assessing the impact of some of the constraints identified for offshore wind development (van Haaren and Fthenakis, 2011).

II.b.2.4. Considerations for a National Macroalgae Assessment. Constraints examined in these studies closely align with the ones that potentially would be important for macroalgae production. However, there are some additional considerations and uncertainties. One of the difficulties is the legal and jurisdictional uncertainty for this new development area and the differences in siting within state waters (up to 3 nautical miles) versus federal waters (Figure 3). In addition, there is uncertainty in the regulatory process itself. For example, kelp harvest could be considered as an aquaculture activity, and, as such, could be regulated by the National Oceanic and Atmospheric Administration (NOAA) and state agencies or could be considered as renewable energy that would be regulated by the Bureau of Ocean Energy Management, Regulation and Enforcement (BOEMRE).

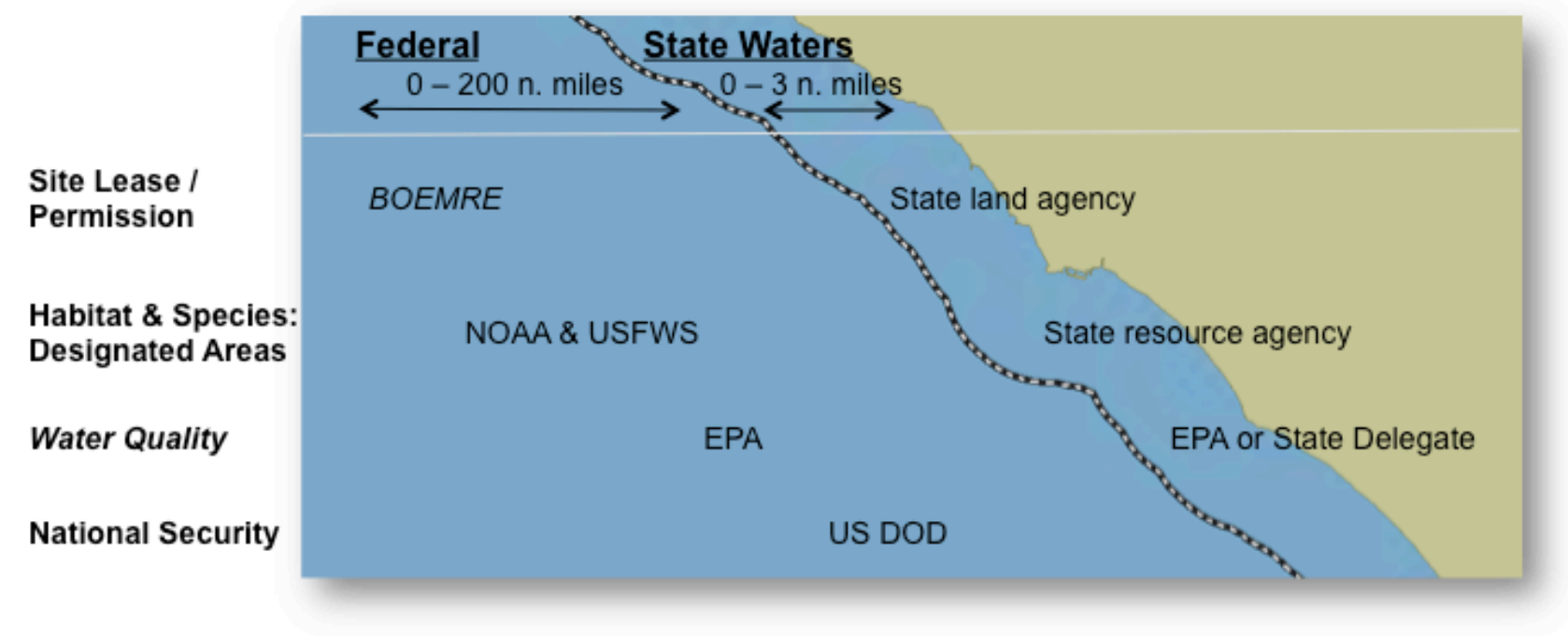

Figure 3. Legal Jurisdiction in marine waters often depends on the distance from shore. State agencies have regulatory jurisdiction in many cases within 3 nautical miles from the coastline.

In addition to regulatory uncertainties in state waters, the scale of analysis for many of these site-specific studies is different from a national assessment. Consequently, the relative importance of some of the features, such as shipwrecks, likely have a negligible impact in production figures when calculating the total national potential.

The assessment of national production potential for macroalgae biomass differs from many renewable and aquaculture studies where the objective is to identify the best site within a limited region for development of a project. The approach to ranking constraints needs to be adapted from selecting areas that would be 
best for an investment to areas that have the least constraint level for a commercial macroalgae production facility. Pairwise comparison, for example, becomes problematic when assessing the constraint level with multiple high constraint criteria. Because the importance of each constraint is ranked against the importance of all other constraints in the study, constraints that may equally limit the occurrence of a macroalgal facility in a site would not appear to have the same constraint level. The high level of constraint for an area should be maintained no matter the number of constraints examined.

\section{II.b.3. Conceptual Model for Marine Use and Conflicts}

II.b.3.1. Conceptual Model Creation. Based on identified limitations from aquaculture and renewable resource studies as well as needs specific for macroalgal production, a conceptual model for assessment constraints was created and the approach to represent each element was determined (Table 2 [a-c]). These include the assessment of legal, environmental, and competing use constraints. An approach to examine access and infrastructure constraints is planned for follow-on years for this study. In developing the conceptual model, the terms for constraint shown in Table $\mathbf{2}$ [a-c] were used. Constraint levels were ranked as follows:

High: Likely exclusion in area. Other uses are very place-specific and competitive for use of area. May include legal exclusion of aquaculture in site.

Moderate: Known barrier to development. Other uses in site are specific to place, but may be compatible with development. Prior development has created conflicts for aquaculture/renewable energy development. Example: use of coastal waters under jurisdiction of states for renewable energy.

Low: Other uses are present, but likely compatible with macroalgae development. Example: NOAA fishing restriction areas

No or Null Constraint: No known constraint in area.

\section{II.b.4. Geospatial Model Development and Application to Study Sites}

II.b.4.1. Geospatial Analysis. A dataset for each constraint listed in Table 2 [a-c] was developed, and each was converted to raster format at a $250 \mathrm{~m}$ resolution and categorized according to the constraint level listed in Table 2 [a-c]. Most are self-explanatory and listed in the table. However, the approach to create the visual acuity model was more complex and is detailed below. 


\begin{tabular}{|c|c|c|c|c|}
\hline Conflicting Use & Data Source & Identification & Logic & $\begin{array}{l}\text { Constraint } \\
\text { Level }\end{array}$ \\
\hline $\begin{array}{l}\text { Conservation } \\
\text { Zones }\end{array}$ & $\begin{array}{l}\text { NOAA Marine } \\
\text { Protected Areas }\end{array}$ & $\begin{array}{l}\text { Areas of no take, no } \\
\text { entrance, multi-zones with } \\
\text { no take or no vessel } \\
\text { activity. }\end{array}$ & $\begin{array}{l}\text { Marine conservation areas are created to protect and } \\
\text { preserve unique marine habitats and species. Legally } \\
\text { there are different uses of their waters permitted } \\
\text { depending on the type of area and jurisdiction. } \\
\text { However, macroalgae development in those areas that } \\
\text { do not permit public entrance, fishing, or vessel } \\
\text { activity would be highly unlikely as related activities } \\
\text { with macroalgal development would likely conflict } \\
\text { with the goals of these sanctuaries. }\end{array}$ & High \\
\hline State Waters & Shoreline & $\begin{array}{l}\text { Coastline buffer } 3 \text { miles } \\
\text { offshore. }\end{array}$ & $\begin{array}{l}\text { Legally, permitting of offshore aquaculture facilities } \\
\text { have been challenging in state waters, in part due to } \\
\text { the different regulations between states and states } \\
\text { opposition to aquaculture activities. }\end{array}$ & Moderate \\
\hline
\end{tabular}




\begin{tabular}{|c|c|c|c|c|}
\hline $\begin{array}{l}\text { Habitat Areas of } \\
\text { Particular } \\
\text { Concern } \\
\text { (HAPC) }\end{array}$ & NOAA HAPC & All areas & $\begin{array}{l}\text { Habitat areas of particular concern have been } \\
\text { identified by NOAA as habitats to watch. Though } \\
\text { there may be no explicit regulations regarding these } \\
\text { areas, any commercial activity would likely encounter } \\
\text { barriers to activities in these zones. }\end{array}$ & Moderate \\
\hline \multirow[t]{2}{*}{$\begin{array}{l}\text { Essential Fish } \\
\text { Habitats (EFH) }\end{array}$} & \multirow[t]{2}{*}{ NOAA EFH } & Fishing Restrictions & \multirow{2}{*}{$\begin{array}{l}\text { Essential Fish Habitats - Fishing restrictions often } \\
\text { limit the type or season of harvest to protect sensitive } \\
\text { or important species. Kelp production may be seen as } \\
\text { providing additional disturbances to these sensitive } \\
\text { areas or may provide concerns about potential changes } \\
\text { to community compositions. However the main } \\
\text { objective of these zones is to limit human take, not } \\
\text { limit activities. On the other hand, conservation areas } \\
\text { are established to protect the physical area, not the } \\
\text { species, so the barrier to development of activities in } \\
\text { these areas would be higher. }\end{array}$} & Low \\
\hline & & Conservation Areas & & High \\
\hline
\end{tabular}




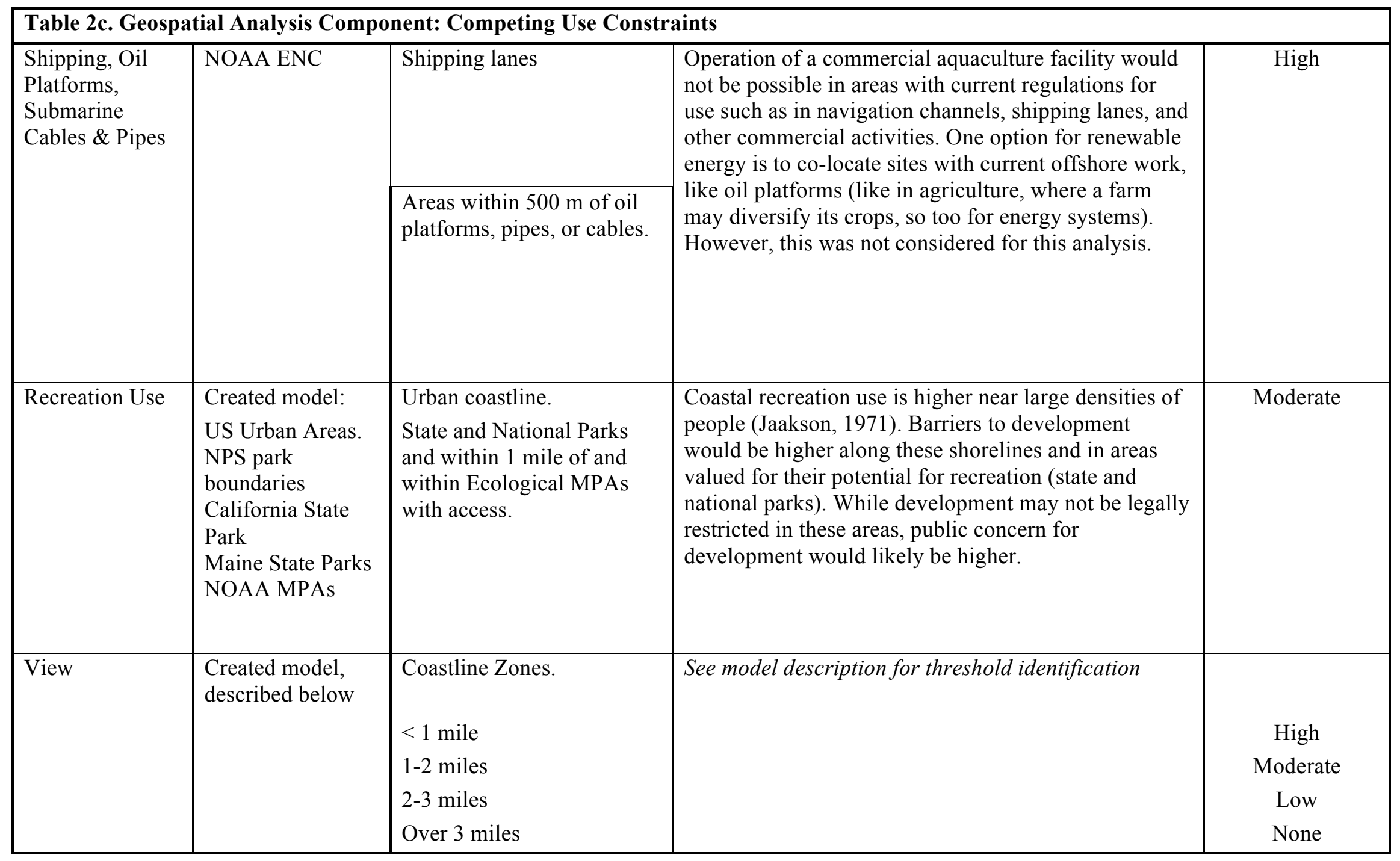


II.b.4.2. View Assessment Analysis. The visual impact of wind energy (Figure 4) has been considered as the primary barrier to public acceptance, and, for renewable wind facilities, a range of approaches to assess the visual impact of these structures exists. A similar visual impact could exist for structures associated with macroalgae cultivation facilities. Molina-Ruiz (2011) used a visual field determination calculation to determine the level of visual impact of wind turbines with a height of $50 \mathrm{~m}$ :

$$
\mathrm{Y}-\mathrm{L}=\mathrm{R}
$$

where $\mathrm{Y}$ is the height $(\mathrm{m})$ of object; $\mathrm{L}$ is the maximum object size that is visible, defined as pi/180 * $5 / 60 \mathrm{~d}$; and $\mathrm{d}$ is the functional distance.

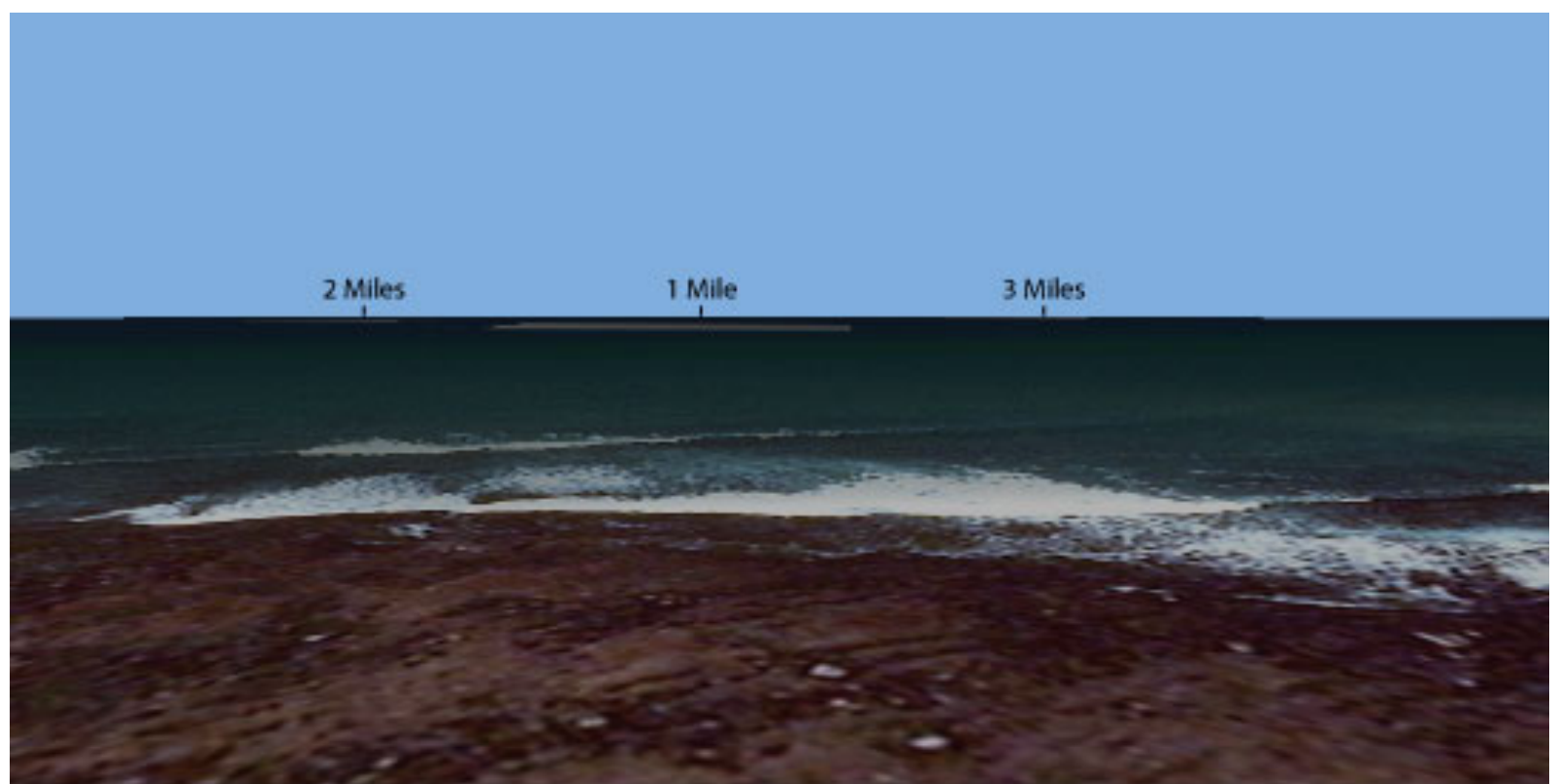

Figure 4. Visualization of potential macroalgae cultivation structures. Floating macroalgae facility dimensions were $500 \mathrm{~m} \times 500 \mathrm{~m}$ in size with a height of $8 \mathrm{~m}$. These were mapped 1 mile, 2 miles, and 3 miles offshore from an observation point on shore.

Molina-Ruiz (2011) defined three levels of visual impact, where objects are still visible: $0-15 \mathrm{~km}$ distance as "High Impact", 15-25 km as "Medium Impact", and greater than $25 \mathrm{~km}$ as "Low Impact", based on the derived $\mathrm{R}$ or observable height of the object. The visual impact of a floating structure with minimal height would be very different than that of a $50 \mathrm{~m}$ tall wind turbines. Using Eq. 1, the percent of object visible for an assumed $8 \mathrm{~m}$ high facility from the shoreline was calculated (Table 3):

\begin{tabular}{|c|c|c|c|c|c|}
\hline $\begin{array}{c}\text { Distance } \\
\text { (miles) }\end{array}$ & Y (m) & $\mathbf{L}_{\max }$ & $\overline{\mathbf{R}}$ & Percent Visible & Impact \\
\hline 1 & 8 & 2.3 & 5.7 & $70.8 \%$ & High \\
\hline 2 & 8 & 4.7 & 3.3 & $41.5 \%$ & Intermediate \\
\hline 3 & 8 & 7.0 & 0.98 & $12.3 \%$ & Low \\
\hline
\end{tabular}


Objects were mapped at a test location off the California coast (Figure 2). Originally, we intended to use the $R$ thresholds of Molina-Ruiz to determine the low, intermediate, and high impact. However, it was evident that the overall size of the floating structures $(500 \mathrm{~m} \times 500 \mathrm{~m})$ was much larger than the singular point in space of Molina-Ruiz (2011). Thus, the thresholds for percent object visible were used rather than the $R$ values.

In ArcGIS, buffering the shoreline and clipping to the EEZ extent created three visual impact zones.

When considering visual impact, it is also important to consider the number of people being impacted. In addition, viewing angle could alter the visibility of the floating facilities. Views from coastal hills or mountains could yield better views of facilities than a ground observer. However, for the purpose of this initial assessment - to deliver a rough order of magnitude understanding of impact - they were not assessed.

II.b.4.3. Modifications to Ranking. After a dataset was created to represent each constraint, a rule-based decision tree analysis was used to develop the constraint level for the individual constraint themes: legal, environmental, and competing uses, as well as the overall constraint score (Figure 5). Each cell within the dataset was evaluated and assigned a constraint level.

II.b.4.4. Results for Applying Selection Constraints Model to Demonstration Areas. Constraints for legal (Figure 6), environmental (Figure 7), and competing uses (Figure 8) were mapped. An overall constraint level was assessed for each study area (Figure 9). Within the study areas, most of the areas within state waters $(88 \%)$ were considered to have a high level of constraint, while in the entire EEZ, only approximately $12 \%$ of the area is considered to have a high level of constraint (Table 4). Areas farther from shore appear to have fewer constraints, but these areas would likely be more expensive to access and build infrastructure. Within the two study areas, there were also different levels of constraints. A higher proportion of the area in Southern California contained constrained areas than in the Gulf of Maine.

Table 4. Constraint level classification in study areas. In state waters, most areas are classified as having a "High" constraint level.

\begin{tabular}{|l|c|c|c|c|}
\hline \multirow{2}{*}{ Zone } & \multirow{2}{*}{ Total Area ${\left(\mathbf{k m}^{2}\right)}^{*}$} & \multicolumn{3}{|c|}{ Constraint Level Area $\left(\mathbf{k m}^{2}\right)$} \\
\cline { 3 - 5 } & 45,000 & Low & Medium & High \\
\hline State Waters & -- & 4,500 & 39,500 \\
\hline $\begin{array}{l}\text { Exclusive } \\
\text { Economic Zone }\end{array}$ & 468,000 & 380,000 & 30,000 & 58,000 \\
\hline
\end{tabular}




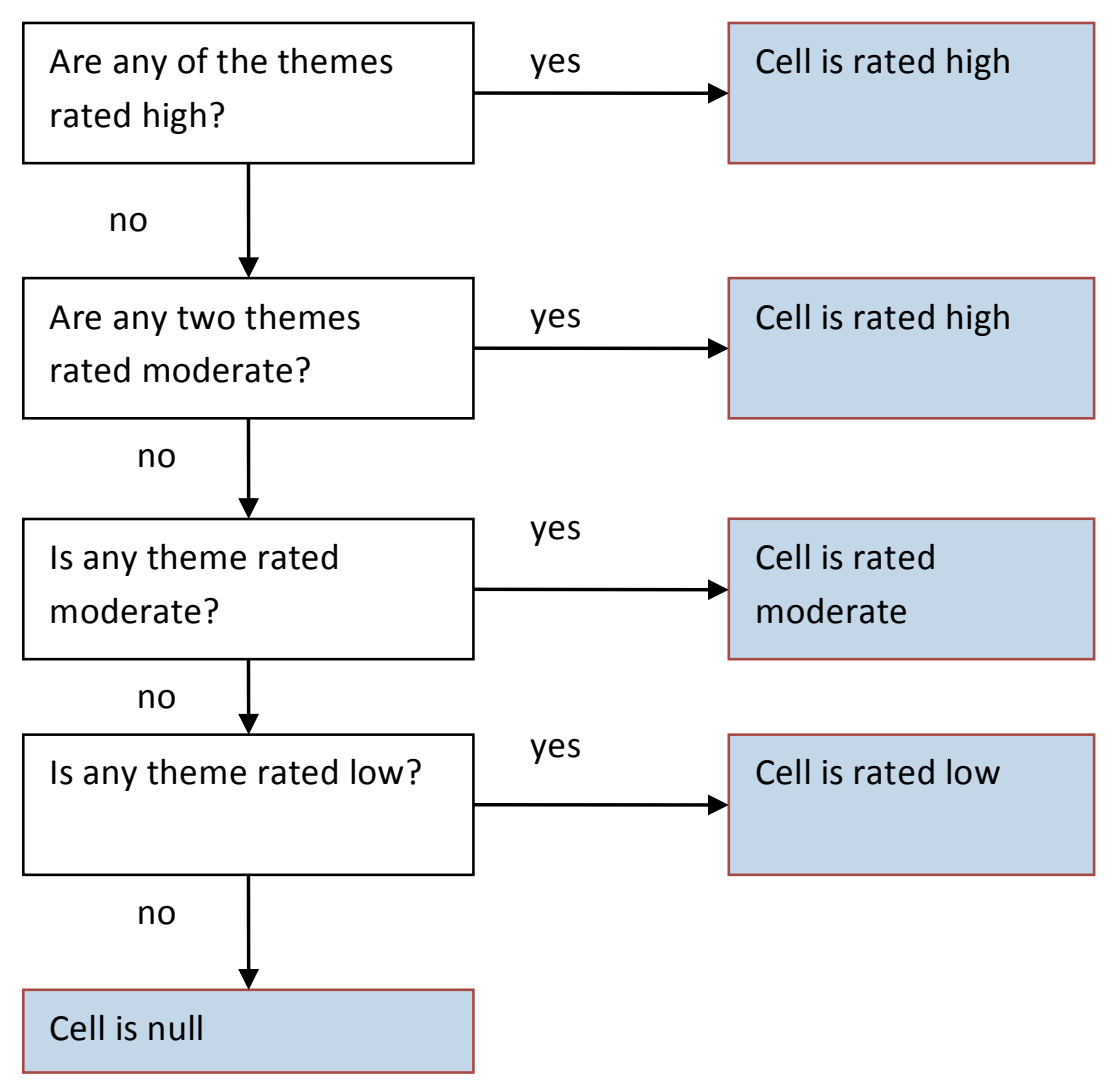

Figure 5. A rule-based decision tree for classification of each cell within the study area was used to create final classification for each constraint theme, as well as an overall constraint level for each site. 

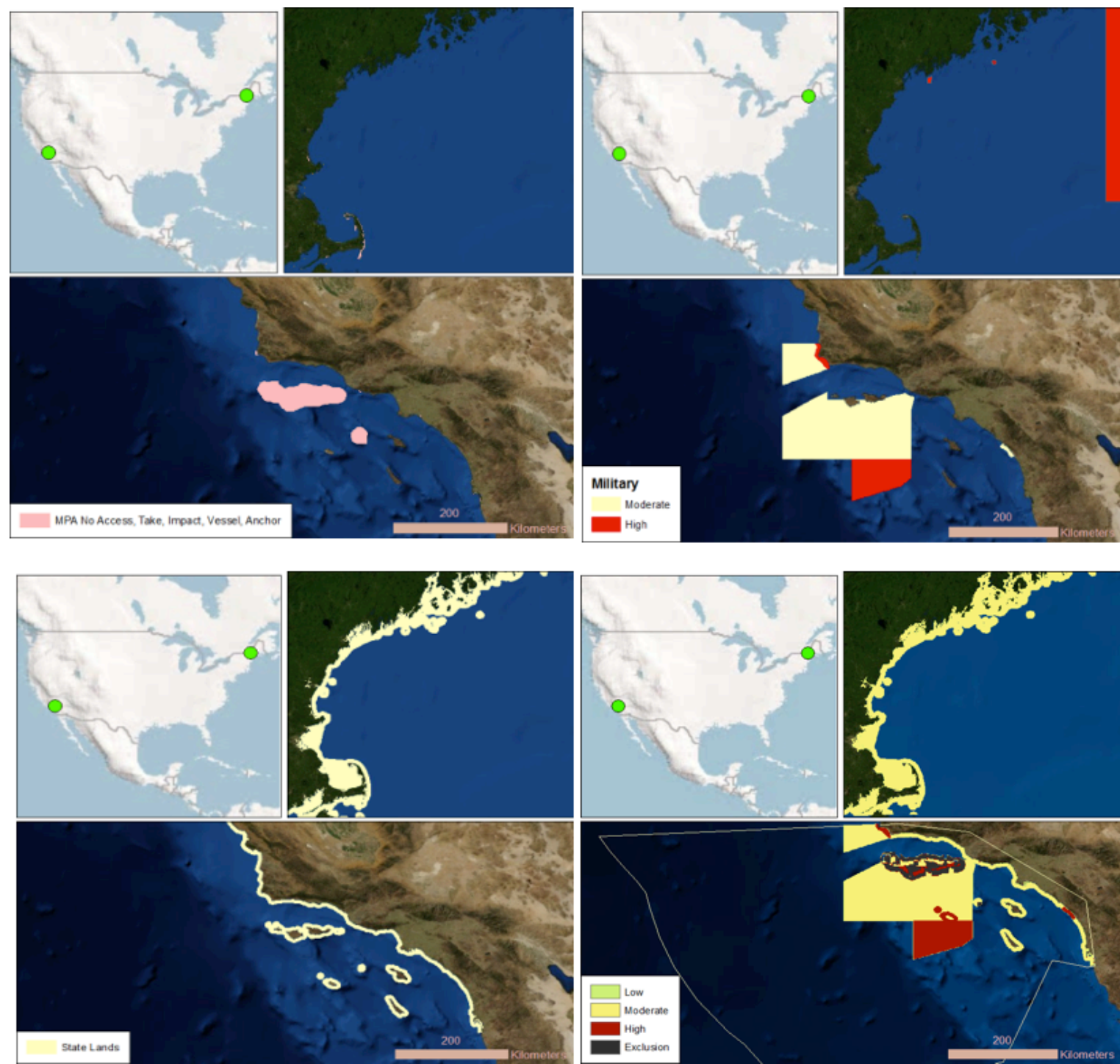

Figure 6. Legal Constraints. Evaluation examined MPA (upper left), Military Use (upper right), and State Marine Zone (lower left). Final Evaluation Map (lower right) used a decision tree to define the level of legal constraint within each $250 \mathrm{~m}$ cell within the study area. Legend: Low - light green; Moderate - yellow; High - Red; Exclusion - black. Demonstration areas are identified by green circles. 

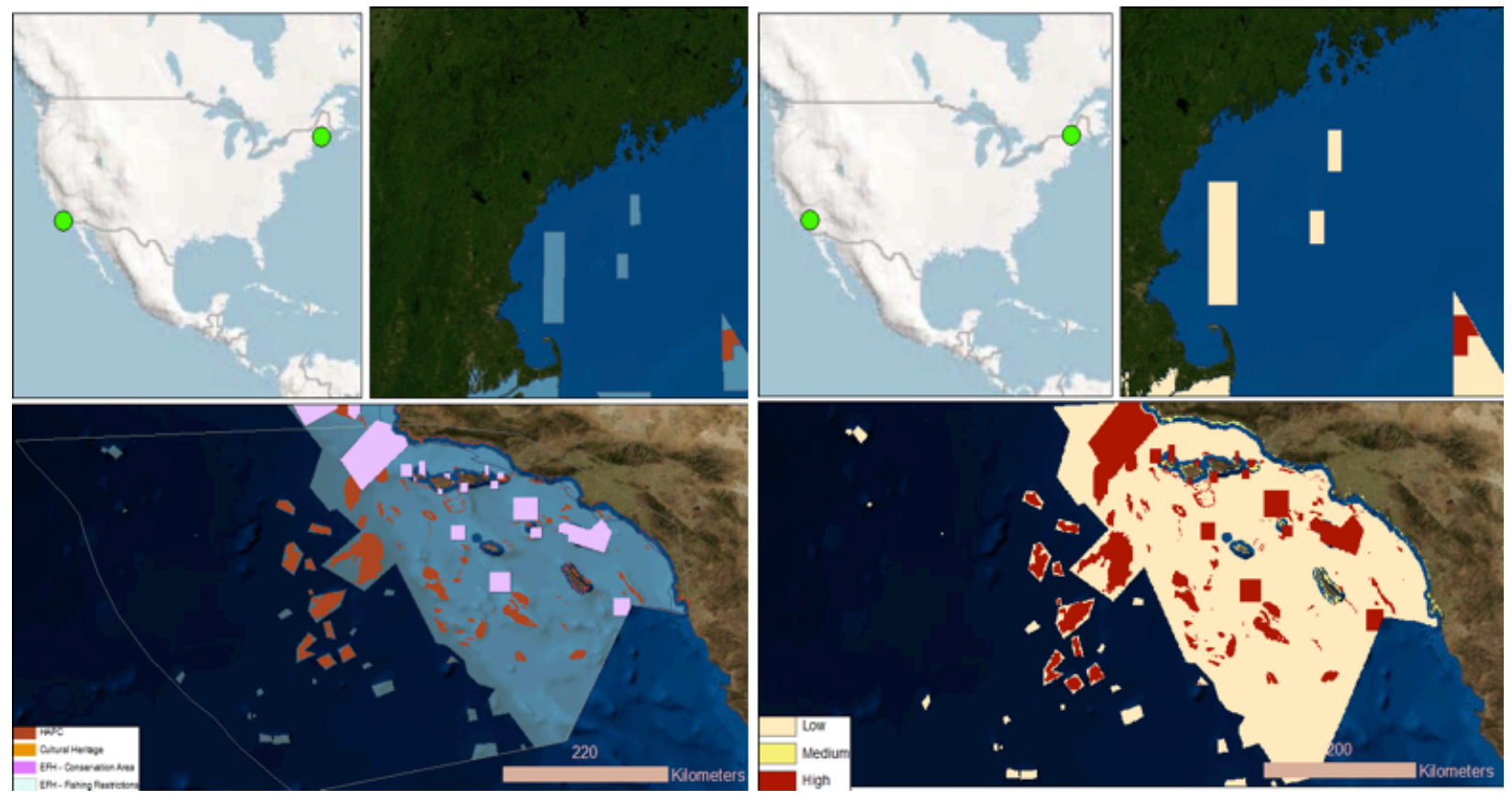

Figure 7. Environmental Constraints. Mapped constraint areas (left) with final environmental constraint level (right). Legend for mapped constraints: Habitat Areas of Particular Concerns (HAPC) - red; Cultural Heritage - orange; Essential Fish Habitat (EFH)-Conservation Area mauve; Essential Fish Habitat (EFH)-Fishing Restrictions - light blue. Legend for constraint level: Low - tan; Medium - yellow; High - red. Demonstration areas are identified by green circles. 

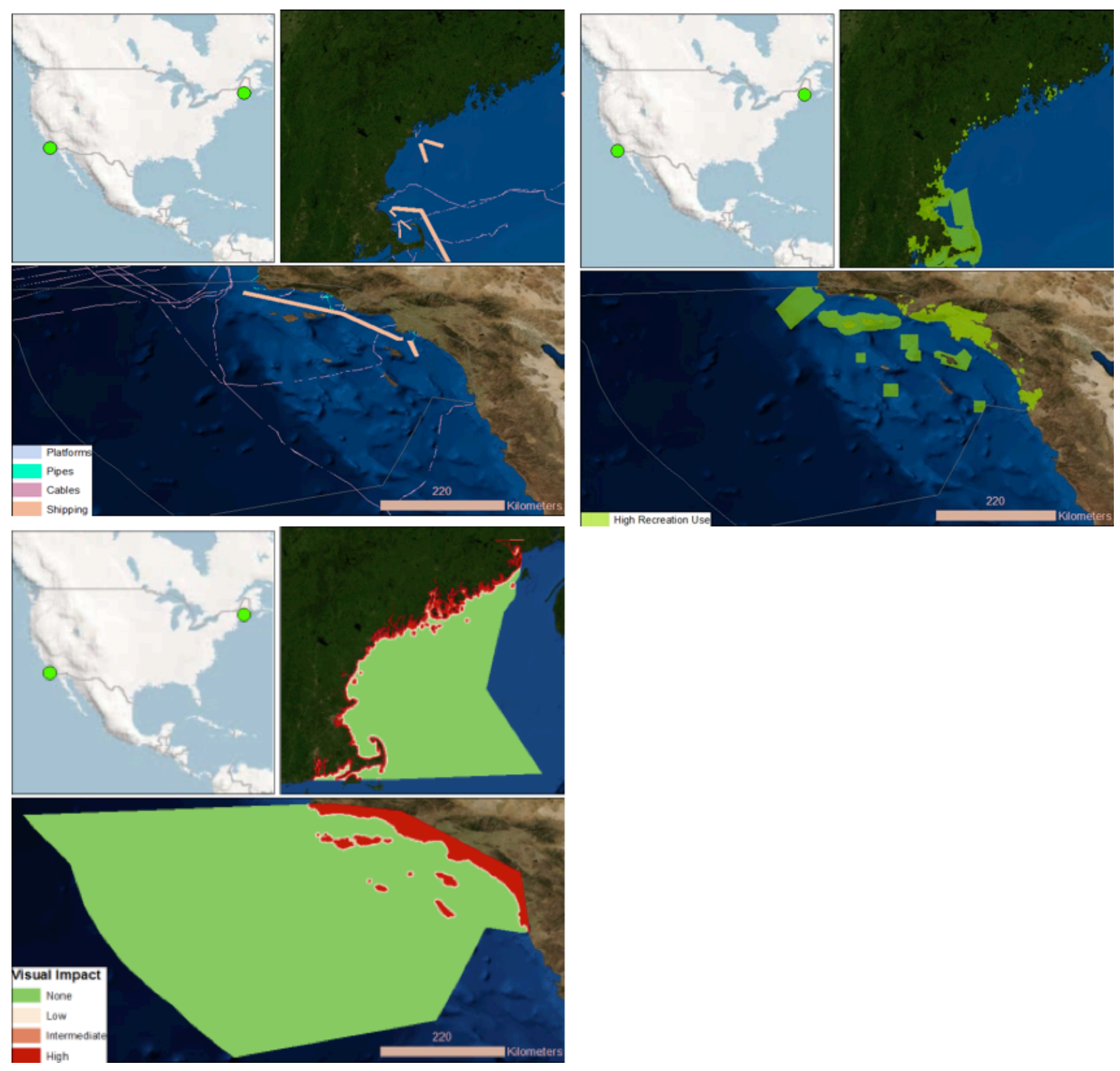

Figure 8. Competing Use Constraints. Cables and navigation (upper left), recreation use (upper right) and visual acuity assessment (lower left). Legend for Cables and navigation: Platforms - light blue; Pipes - aquamarine; Cables - mauve; Shipping - light orange. Legend for recreation use: High - green. Legend for visual acuity: None - green; Low - pink; Intermediate - orange; high Red. Demonstration areas are identified by green circles. 


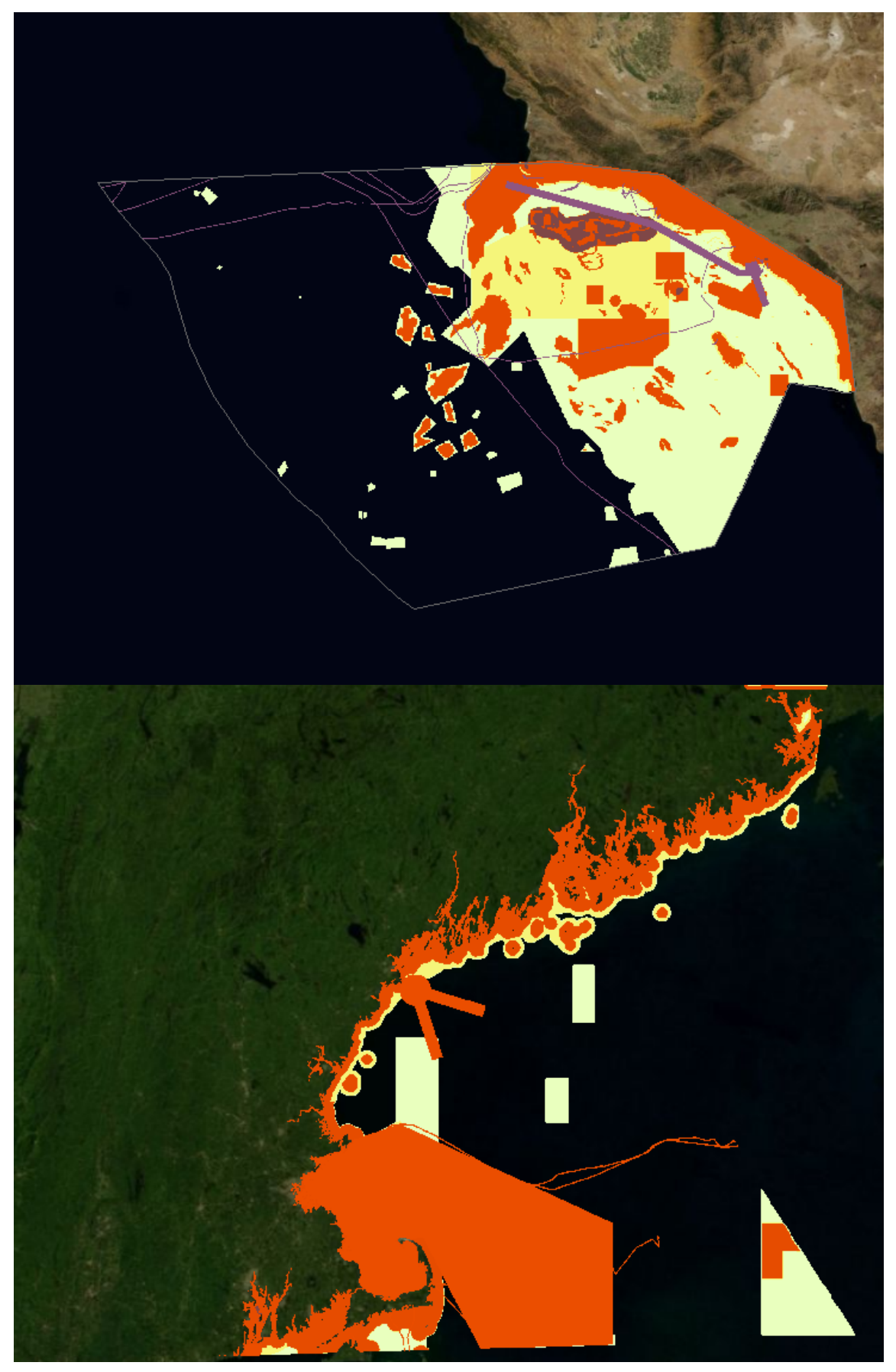

Figure 9. Final constraint level for study areas. Legend for constraint level: High - orange; Moderate-yellow; Low - light green. Areas not shaded have a null constraint level. 


\section{II.b.5. Assessment of Uncertainty}

II.b.5.1 Score Sensitivity. While constraint levels were determined based on available information, there were some uncertainties in the classifications and within the geospatial datasets. One of the areas of concern was the large zone in the Gulf of Maine study area that was rated as "high" constraint due to the delineated shipping zone. In this case, alternate scoring of the level of impact would shift final results. Focusing on themes that contribute the largest areas to "high" and "moderate" constraint level to assure quality in underlying datasets would be important in future years. In addition, uncertainty in scores can be used to produce a range of production potential values based on scenario-specific assumptions for constraints. This can be useful in assessing uncertainty in future production.

II.b.5.2. Project Comparison. Results were compared to NOAA's California Ocean Uses Atlas Project (Figure 10) (Wahle et al., 2009), a participatory GIS project where participants identified key areas for various uses interactively on a map. Various uses were counted for each grid cell, and cells were ranked from low to high based on the number of uses per cell. While there was a general agreement between our study and the Ocean Use Atlas hotspots for competing uses, areas in our study are predicted to be slightly more constrained. It is likely that the differences in approaches between a generalized counting of the number of constraints per grid cell, and our approach to determine the functional level of constraint per grid cell were the causes for this difference.

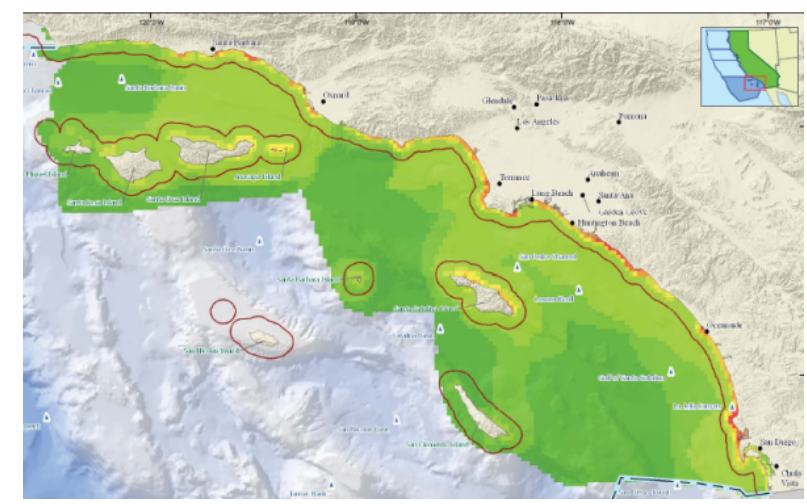

Figure 10. California Ocean Uses Atlas for Recreation Use. The recreation use assessment used in this assessment had slightly higher scores than the Ocean Uses Atlas.

\section{II.b.6. Future Plans}

Our next step, contingent on future interest and needs of the Biomass Program, would be to apply methods across U.S. shorelines for a national assessment and to merge the results of the constraints modeling with that of macroalgal production as described in a later section. We are also planning a broader peer review of this analysis.

We also plan to develop a method to examine access and infrastructure constraints, tying feasibility and viability to cost. For a preliminary assessment, these mapped levels of constraints can be used to adjust production projections to cover only areas where production is possible, such as in areas with only a Low or Null constraint level. However, in some areas, production may be possible, but it may take more time and resources to overcome barriers. In the following years for this project, we would develop a potential 
cost associated with a constraint. This would enable identification of areas with the most potential for development and a broad understanding of the financial viability when overlaying with production potential.

The output of the model would be used to limit cultivation activities to areas considered compatible with existing uses of U.S. marine waters.

\section{II.c. The Biophysical GroWth Model FOR Siting ProduCtion ACTIVITIES - A GIS-BASED RESOURCE ASSESSMENT}

\section{II.c.1. Background}

An initial environmental resource assessment and biophysical growth model for macroalgae was developed to provide estimations on national offshore cultivation potential and biomass production. The main elements that feed into the model plus the output as total biomass are shown in Figure 11. The Overall process diagram is referred to as the Macroalgae Resource Model, which includes the Growth Model and limits imposed by the Conflicting Use and Infrastructure Constraints Model described in the previous section.

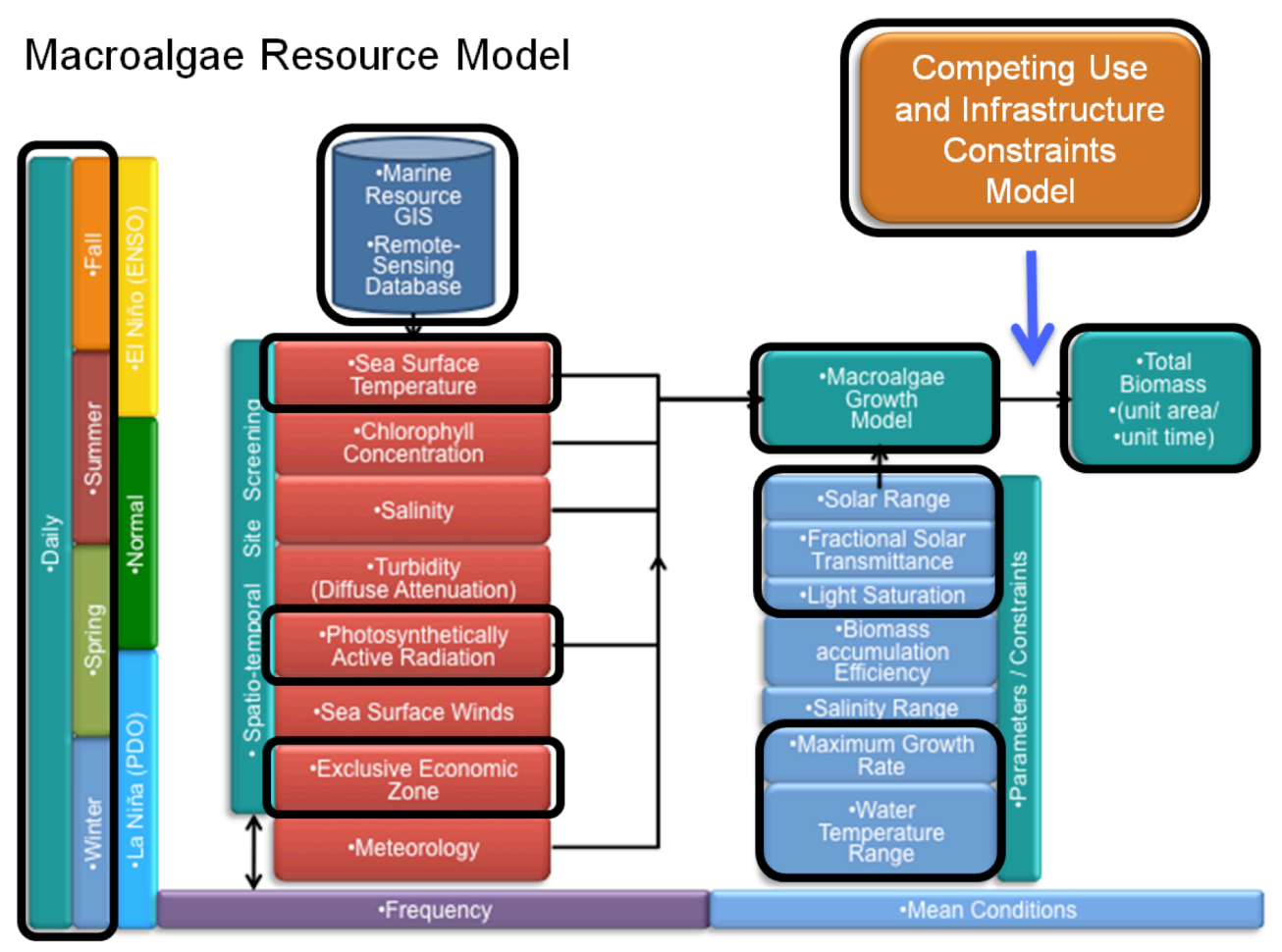

Figure 11. Framework for the Macroalgae Growth Model and the limits imposed by constraints derived from conflicting uses and infrastructure needs described in the previous section. The latter would limit areas considered suitable for siting cultivation activities.

The Growth Model is made up of several overarching components. The temporal component enables evaluation of growth conditions at a range of temporal scales, from the daily, monthly, seasonal, in addition to event-driven analysis such as La Niña or El Niño type conditions. The spatiotemporal components - fusing both time and space - includes elements such as Sea Surface Temperature (SST), 
turbidity, Photosynthetically Active Radiation (PAR), and salinity, all of which are derived from satellitebased remotely-sensed imagery and retrieved from NASA's OceanColor Data portal at: http://oceandata.sci.gsfc.nasa.gov/MODIST/Mapped/8Day $/ 4 \mathrm{~km} /$. The data are all sourced from the Moderate Resolution Imaging Spectroradiometer (MODIS) sensor aboard NASA's Terra satellite. Image products were collected at a $4 \mathrm{~km}$ pixel resolution using an 8-day composite image for the period 2001 to 2010. To initially evaluate long-term mean monthly trends over the ten-year period, all 8-day composite data were processed into mean monthlies. Long-term mean monthlies were then produced using the individual mean monthly data. The spatial-only component, the EEZ (see Figure 2), is our ultimate model domain.

The spatiotemporal components feed the Macroalgae Growth Model, a biophysical growth model heavily driven by light and temperature conditions as has been seen to be the case in other efforts to model macroalgae growth (Graham et al., 2007). Within the growth model are parameters and constraints that can be set for specific species of macroalgae. Results from the growth model are output as total biomass per unit area/per unit time. The black outlined boxes indicate the parameters that received the most attention in current work.

Efforts in three primary areas contributed to developing this physics-based model: 1) a conceptual growth model that defines the primary factors affecting growth rates and natural removal of biomass; 2) an earlyphase numerical growth model with an emphasis on the energy components; and 3) a spatiotemporal modeling framework that provides the required parameters and input data, executes the numerical model, provides classification-based screening, and visualizes the results.

The basis of the conceptual macroalgae growth model is defined by several primary components that govern growth rates, and is simply defined by the following relationship:

$$
G_{\text {gross }}=f(L, T, N)
$$

where $G_{\text {gross }}$ is the gross biomass growth, $L$ is light availability measured as PAR, $T$ is measured as SST, and $N$ is nutrient availability. Light, temperature, and nutrient availability interact in a complex manner to modulate the growth rate (Figure 12).

Light is a function of the incoming solar irradiation modulated by turbidity and shading by fronds of adjacent individuals in a macroalgae stand. It is an indicator of growth rates and feasibility of production. Temperature is also an indicator of growth rates and feasibility of production. There are minimum and maximum temperatures needed for survival and optima within that range. Nutrients can vary with temperature and chlorophyll, with the latter associated with primary production. Physical dynamics such as ocean upwelling affect both temperature and nutrient concentrations.

In marine systems, there are associated phenomena that facilitate the detection of areas of higher nutrient concentrations. For example, special conditions of the sea surface temperature can indicate cold upwelled water coming off the ocean bottom to the sea surface, carrying with it a high-concentration of nutrients, in particular nitrates and phosphates. As a result of the nutrient availability, we are also able to detect concentrations of chlorophyll production through remote sensing. Thus, SST and chlorophyll are reasonable predictors of nutrient concentration in surface waters, and their distributions off the coast of Southern California are shown in Figure 13. Note the cooler water temperatures in areas of upwelling. 


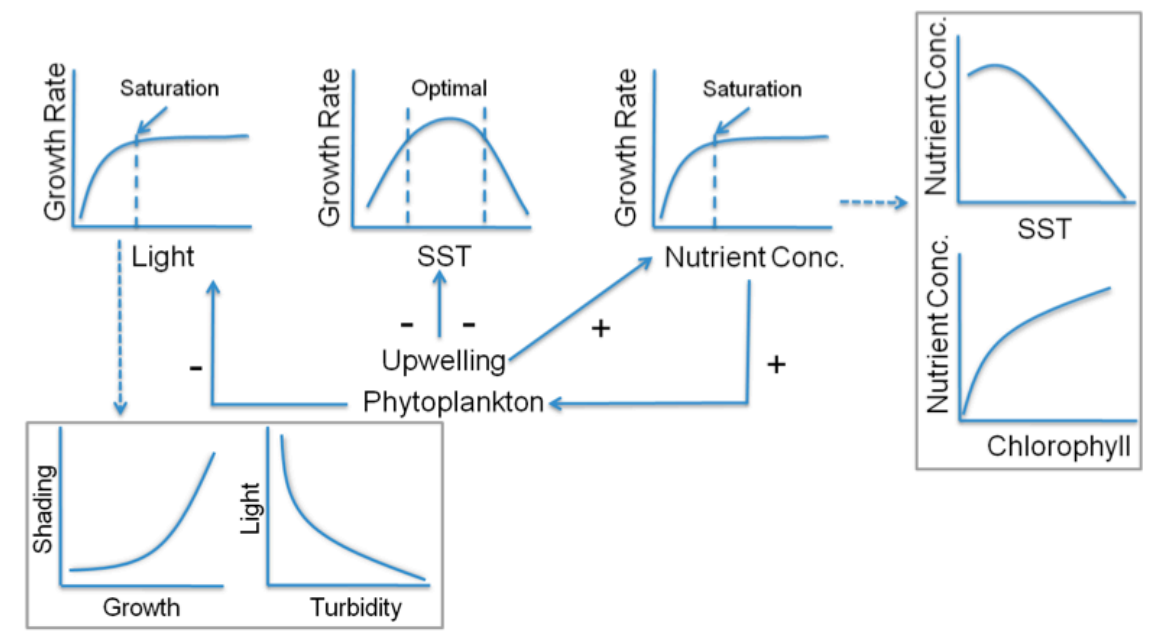

Figure 12. The growth rate of macroalgae is defined by a complex relationship between light availability, water temperature, and nutrient availability. SST is Sea Surface Temperature.

\section{Sea Surface Temperature (C)}

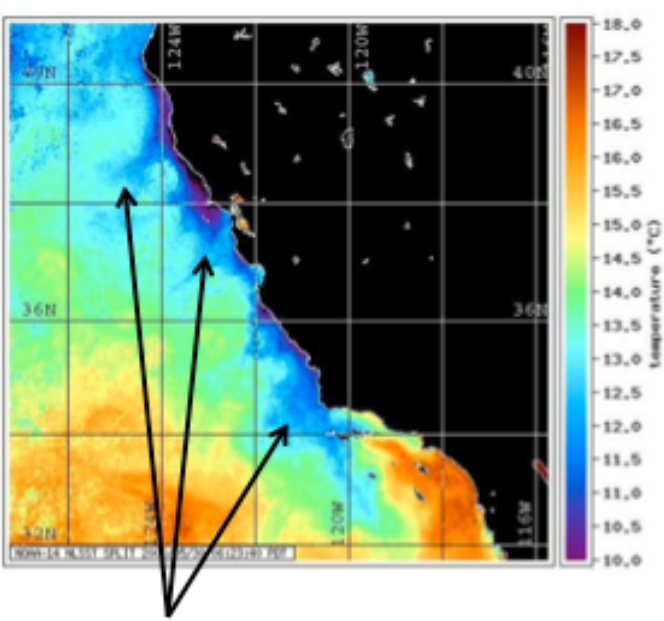

Upwellings
Chlorophyll Concentration $\left(\mathrm{mg} / \mathrm{m}^{\wedge} 3\right)$
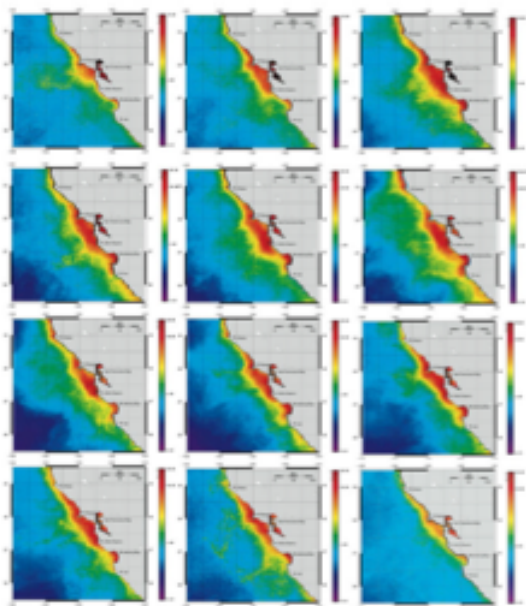

(Mean monthly, 1997-2006, UCSC)

Figure 13. Sea surface temperature and chlorophyll concentration off the coast of Southern California. For SST, locations of coastal upwellings are shown. Chlorophyll concentrations are presented as monthly means during the period 1997-2006.

Standing stocks of kelp biomass are also affected by losses by biotic factors such as grazing by herbivores and senescence and abiotic factors such as waves and currents shown in the following equation:

$$
G_{n e t}=\left[B_{g}-\left(W_{l}+C_{l}+A_{l}+G_{l}\right)\right],
$$

where $G_{n e t}$ is net biomass, $B_{g}$ is biomass growth rate, $W_{l}$ is wave-based loss, $C_{l}$ is current-based loss, $A_{l}$ is age-based loss, and $G_{l}$ is grazing-based loss. 
Each component has thresholds that restrict the abundance of kelp biomass as shown in Figure 14 for the effects of hydrodynamic forces. Resistance to such forces would have to be considered for offshore aquaculture in open ocean conditions. For example, forces exceeding thresholds could limit the distribution of the kelp Saccharina latissima into dynamic environments (Cavanaugh et al., 2011; Buck and Buchholz 2005). However, recent studies that focused on the hydrodynamics and corresponding kelp loss indicate that $S$. latissima can withstand storm events with maximum current velocities of $1.52 \mathrm{~m} / \mathrm{s}$ and wave heights up to $6.4 \mathrm{~m}$. These conditions would set upper levels for viability of this species, and taking such information into account can inform cultivation practices. For example, brood stock grown in a current exceeding $1 \mathrm{~m} / \mathrm{s}$ current would be expected to condition them to be able to withstand drag forces that occur during storm events (Buck and Buchholz 2005).
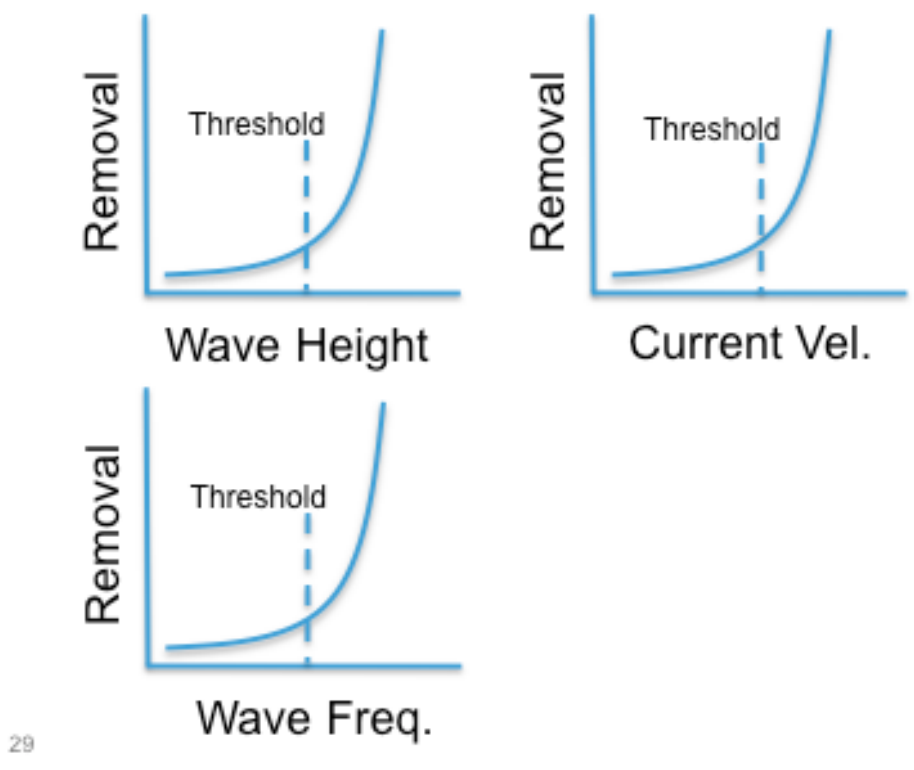

Figure 14. Relationship between wave and current characteristics and removal of kelp from attachments due to excess drag force. Thresholds represent the upper limit of conditions that enable viability of kelp.

\section{II.c.2. Spatiotemporal Analysis of Biophysical Conditions}

Remotely-sensed datasets have been retrieved and processed to 1) conduct a broad-scale screening based on published bio-physical constraints for kelp of the genus Saccharina and 2) provide parameter inputs to the spatially-based, biophysical macroalgae growth model. Members of Saccharina spp. (also classified as Laminaria spp. for some related species) are characterized by features that make them highly suitable as a biomass feedstock: high growth rate, abundance of readily convertible polysaccharides, low cellulose content, and absence of lignins. They are easily cultivated, and S. japonica has the greatest commercial production of all macroalgae species (FAO, 2008), thus making this group a potential biomass source as a biofuels feedstock.

Initial application in our spatiotemporal analysis focused on the retrieval and analysis of remotely-sensed data collected by the MODIS Terra sensor. However, there are many other environmental constraints that 
need to be considered, collected, processed, and incorporated into the macroalgae growth model. For example, buoy data from ARGO (http://www.argo.ucsd.edu/ and http://www.globwave.org) can provide information on wave height and frequency, as well as a validation of water temperature profiles and salinity. They would be incorporated in future work. In general, however, remotely-sensed datasets are considered temporally and spatially more consistent than buoy data and provide data elements not available in in situ data. Data collected by the MODIS Terra sensor are $4 \mathrm{~km}$ pixel resolution, 8-day composites and, for some of the measures such as PAR, minimizes issues with cloud cover. The composites can also compensate for missing data for given days. Data were collected and processed for a 10 -year period extending from 2001 to 2010 . The processed data collection was clipped to the U.S. EEZ; however, source data is available globally.

II.c.2.1. Sea Surface Temperature. SST is a direct result of the intensity of solar insolation and is coupled to a variety of dynamic bio-physical processes (Figure 15). As noted earlier, SST regulates growth rates and sets thresholds for survival and optimal growth. It stimulates movement of water masses and is coupled to both small- and large-scale oceanic circulation (Figure 15a). Fluctuations are both seasonal, due to changes in solar insolation, and short-term, as shown in Figure $\mathbf{1 5 b}$ for hourly changes as a function of both time of day and wind speed (Minnett and Ward, 2000). Cloud cover also contributes to short-term changes in SST.

Remotely-sensed sea surface temperature accounts for $<1 \mathrm{~mm}$ of the upper water surface, also referred to as "skin temperature". The difference between the skin temperature and bulk temperature is largely a function of wind and wave action (general range difference is 0 to 2.5C) (Figure 15b). Mixing-layerdepth and skin-bulk temperature introduce uncertainty and additional complexities into the model. For practical reasons, our Growth Model currently assumes a fixed temperature through a $10 \mathrm{~m}$ deep mixed layer and does not incorporate water temperature responses due to wind and wave action. Future versions of the model would include multi-layer depth-temperature profile.

Spatiotemporal temperature evaluation within the continental U.S. EEZ for long-term mean monthly sea surface temperature is shown in Figure 16, built from 8-day remotely-sensed composites for a ten-year period from 2001 through 2010. Maps are shown for the months of January and August. Clearly evident is the difference due to season in average temperature between the east and west coast EEZ.

The suitability of waters in the U.S. EEZ are classified following rules derived from prior studies on the kelp in the genus Laminaria or Saccharina (Bolton and Luning, 1982; Petrell et al., 1993):

$$
\begin{array}{ll}
\text { High Suitability } & \mathrm{T} \geq 10 \mathrm{C}<16 \mathrm{C} \\
\text { Med Suitability } & \mathrm{T} \geq 5 \mathrm{C}<10 \mathrm{C} ; \mathrm{T}>=16 \mathrm{C}<21 \mathrm{C} \\
\text { Low Suitability } & \mathrm{T} \geq 0 \mathrm{C}<5 \mathrm{C} ; \mathrm{T}>=21 \mathrm{C}<23 \mathrm{C} \\
\text { Not Suitable } & \mathrm{T} \geq 23 \mathrm{C}
\end{array}
$$

This suitability reclassification does not factor in uncertainty. 
A.

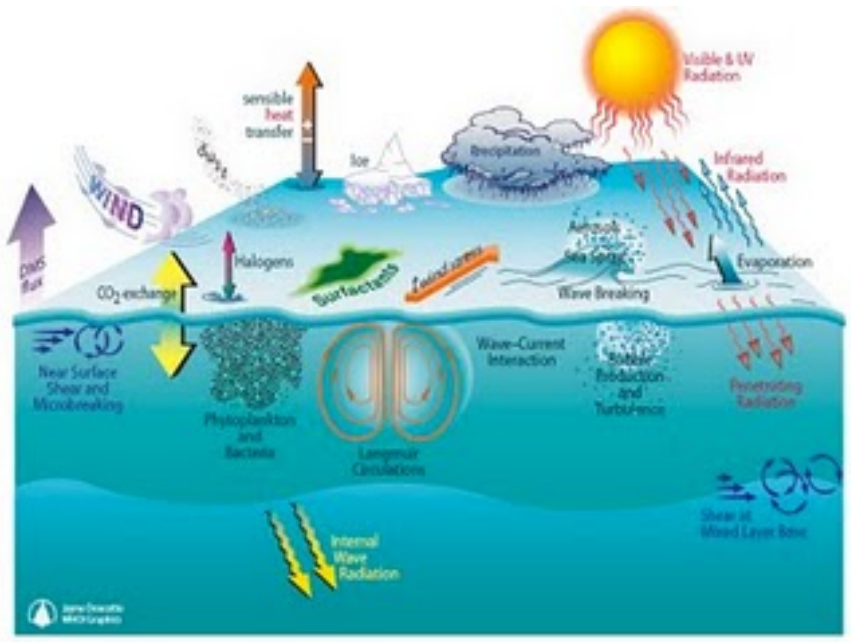

B.

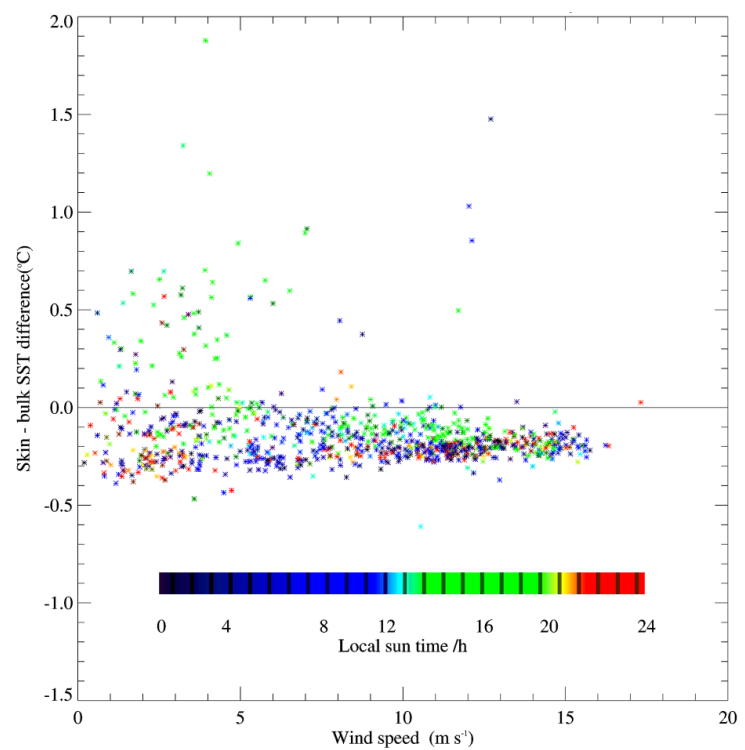

Figure 15. Dynamic relationships stemming from solar insolation and sea surface temperature (SST). A) Processes affected by energy flow from solar insolation; B) Changes in SST as a function of wind speed and time of day (Minnett and Ward, 2000).

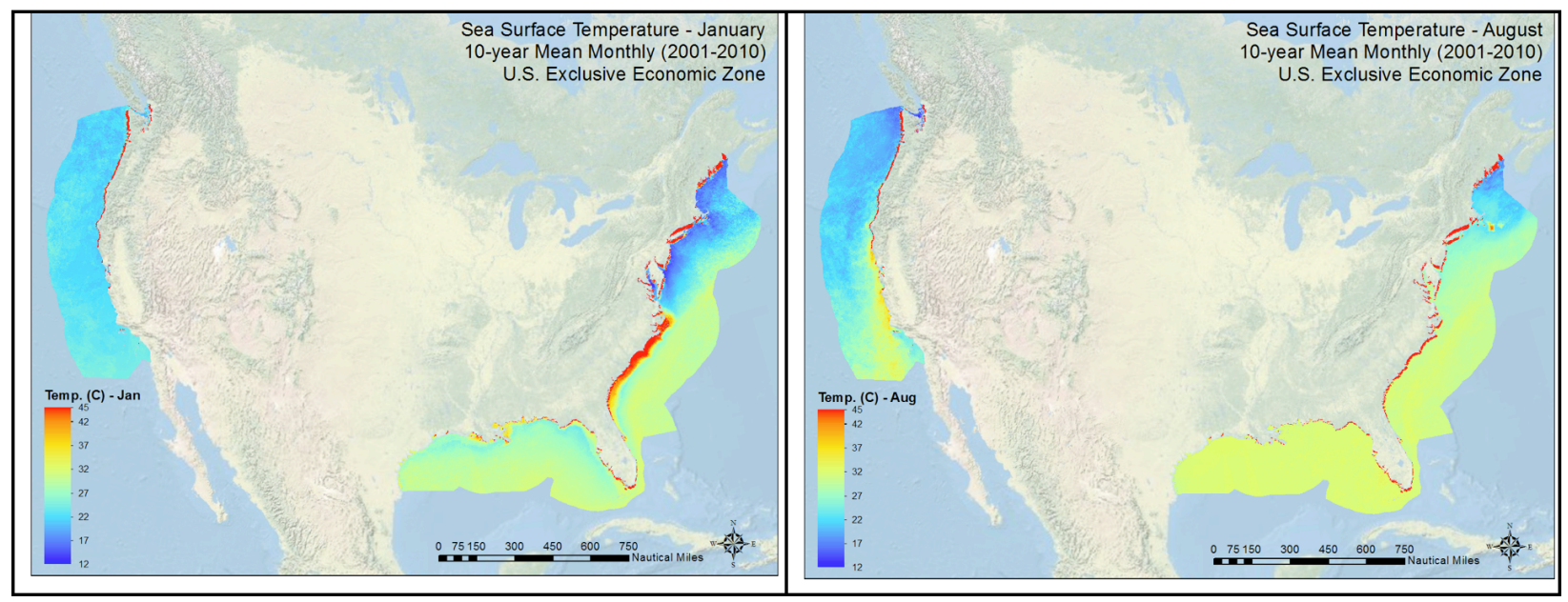

Figure 16. Spatiotemporal temperature evaluation within the EEZ. Maps were built from 8-day composites for a ten-year period from 2001 through 2010 and are shown for the months of January and August. High-temperature values near the shoreline do not accurately reflect sea surface temperature values due to combined land and sea surface temperature within a given $4 \mathbf{k m}$ pixel. Datasets were obtained from MODIS Terra SST (MOD 24).

Monthly temperature maps for waters in the U.S. EEZ off the continental U.S. indicate seasonal variation, but that, overall, areas off the West Coast and New England are suitable year-round (Figure 17). 

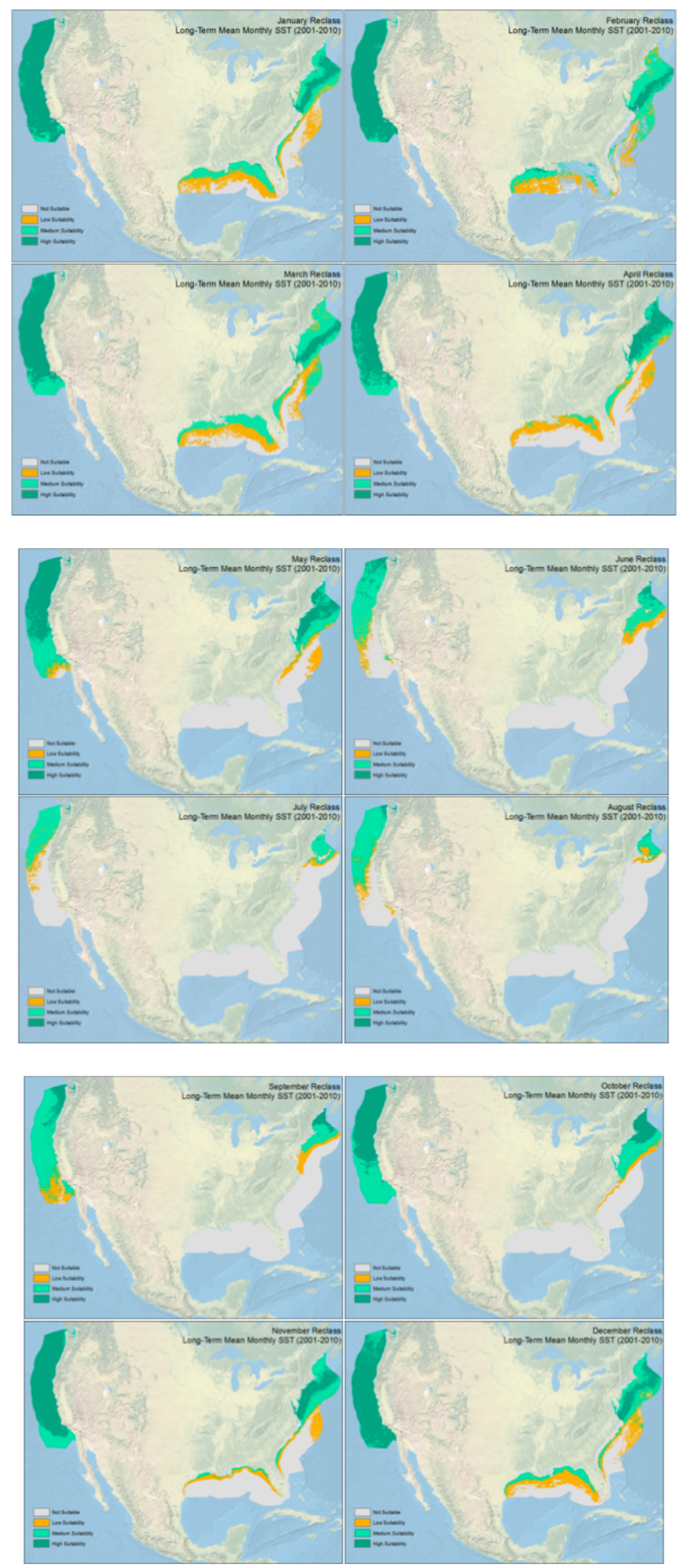

Figure 17. General suitability maps for kelp growth as a function of temperature in the U.S. EEZ off the East and West Coasts of the United States using temperature suitability rules. Maps are shown for months of January to December (top left to bottom right). Legend: Not Suitable - White; Low Suitability - orange; Medium Suitability - aquamarine; High Suitability - Green. 
In contrast, areas off the Mid-Atlantic Coast and in the Gulf of Mexico are not suitable, except narrow nearshore regions in November and December.

II.c.2.2. Photosynthetically Active Radiation. Light of appropriate wavelengths included in measurements of PAR is a requirement for photosynthesis by macroalgae. Spatiotemporal variations in PAR were evaluated within the U.S. EEZ. Eight-day composites from 2001 - 2010 were used to build spatial datasets depicting 10-year mean monthly PAR. Datasets were obtained from the MODIS Terra sensor (MOD 21). In general, PAR increases going from North to South. Seasonal variation is seen in waters in the U.S. EEZ off the East Coast, which is decidedly lower in PAR in the summer month of July (Figure 18).

PAR includes the spectral wavelengths of 400 - $700 \mathrm{~nm}$ needed for photosynthesis, and waters in the U.S. EEZ can be evaluated for their suitability to support photosynthesis as a function of PAR using the Reclassification Rule below (units in moles $/ \mathrm{m}^{\wedge} 2-\mathrm{d}$ ):

$$
\begin{array}{ll}
\text { High Suitability } & \text { PAR }>=6.9 \\
\text { Med Suitability } & \text { PAR }>=4.3<6.9 \\
\text { Low Suitability } & \text { PAR }>=2.6<4.3 \\
\text { Not Suitable } & \text { PAR }<2.6
\end{array}
$$

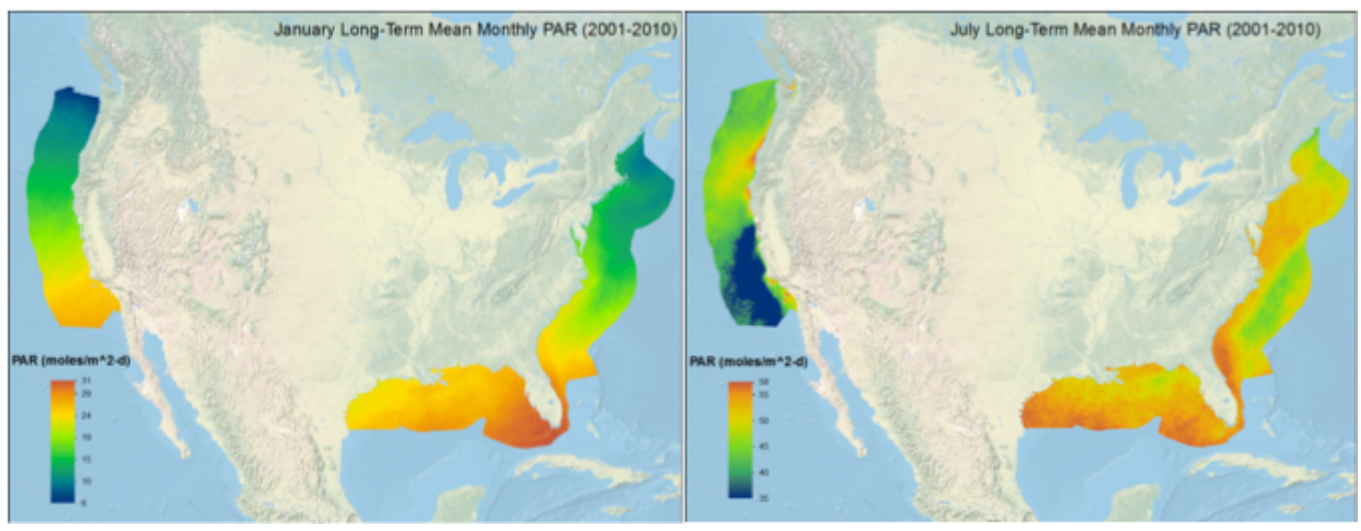

Figure 18. Spatiotemporal PAR evaluation within the EEZ. Shown are maps depicting 10-year mean monthly PAR for January and July built from 8t-day composites from 2001-2010.

An example of suitability analysis is shown for the month of December using a long-term dataset covering 2001 - 2010 (Figure 19). During this month, 'high-suitability' PAR is found in virtually the entire continental U.S. EEZ, and, thus, available PAR is not considered to be a primary environmental constraint. 


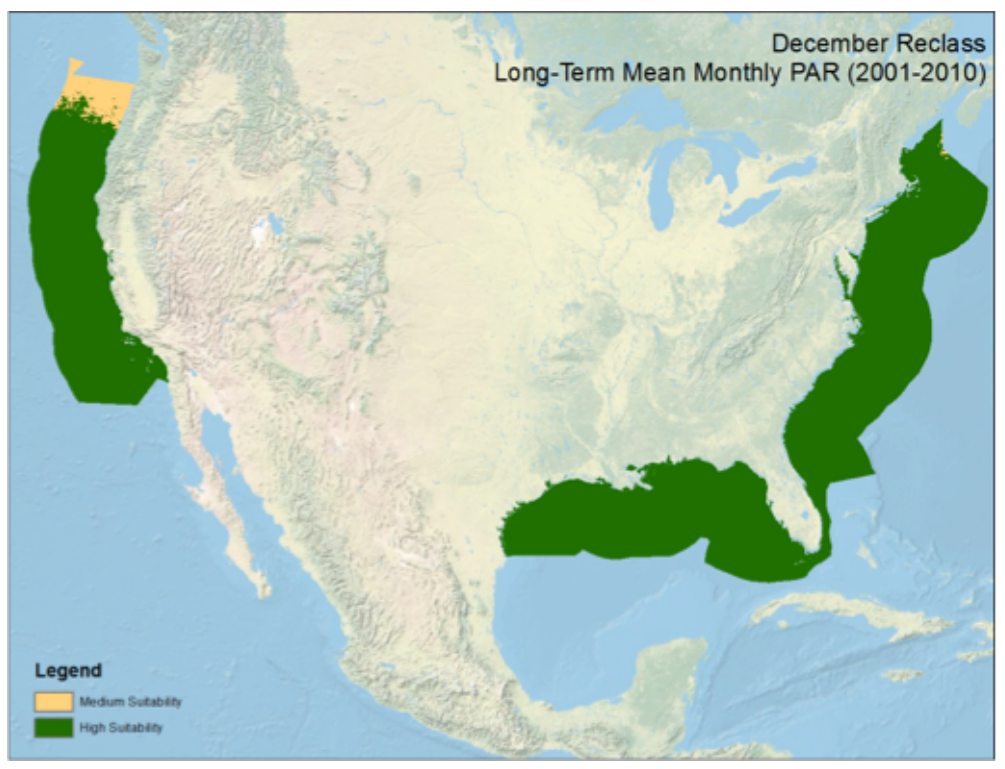

Figure 19. Suitability map for kelp growth as a function of Photosynthetically Active Radiation in the U.S. EEZ off the East and West Coasts of the United. States. This example shows the composite suitability for December 2001-2010 using PAR suitability rules.

\section{II.c.3. Macroalgae Growth Model}

II.c.3.1. Growth Model. The Macroalgae Growth Model is based on estimation of net biomass growth of individual plants, which is derived by correcting gross biomass growth (i.e., $G_{\text {gross }}$ described above in Equation 2) for the energy lost due to respiration. This relationship is described by the net biomass growth equation (Martins and Marques, 2002):

$$
G_{\text {net }}=G_{\text {gross }}-R
$$

where $G_{n e t}$ is net growth, $G_{\text {gross }}$ is gross growth, and $R$ is respiration. To estimate $G_{\text {net }}$ requires additional considerations related to respiration and the relationship between photosynthesis and light.

Photosynthesis, which was shown in Figure 12 to reach saturation with increasing PAR, is further modulated by the algal morphology, namely by the area of the blade or frond, which represents the photosynthetically active portion of the alga. This relationship is described as

$$
P=f\left(I, B_{a}\right)
$$

where $P$ is photosynthetic rate, $I$ is the photon flux density or light availability, and $B_{a}$ is the area of the blade. To calculate light availability, standard solar trigonometric functions are calculated hourly for each day of the year. Remotely sensed PAR is used for vertical irradiance using Mean 8-day composite data for each day in the 8-day period. Incident light at the sea surface is attenuated by reflectance, refraction, and extinction as it enters and penetrates the water column, and appropriate corrections are made to PAR measurements in determining light availability to the algae. Light Reflectance at the sea surface is 
determined by a power-series relationship (Anderson, 1974; Jackson, 1987), and the Subsurface Light Angle (Figure 20) is calculated using Snell's Law and seawater refractive index of 1.33.

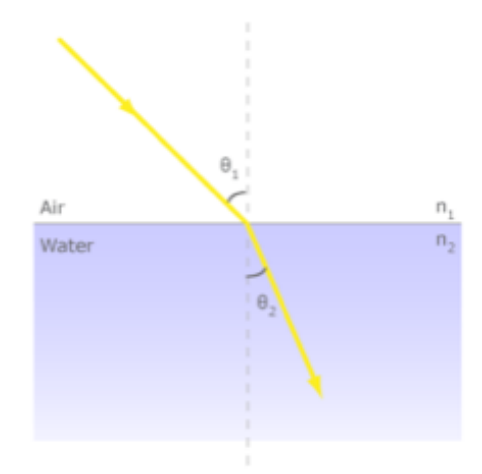

Figure 20. Subsurface Light Angle. The refraction of light as it moves from air to water.

Light extinction, determined using Beer's Law, is applied to extinction at mid-depth:

$$
I_{z}=I_{o} * e^{-k z}
$$

where $I_{o}=$ irradiance; $k=$ light extinction coefficient; $z=$ depth.

The loss of metabolic energy due to Respiration, $\mathrm{R}$, is calculated as a function temperature (Martins and Marques, 2002):

$$
\mathrm{R}=\mathrm{R}_{\max 20} * \theta^{(T-20)}
$$

where $\mathrm{R}_{\max 20}$ is the maximum respiration at $20^{\circ} \mathrm{C}, \theta$ is the constant 1.047 , and $T$ is temperature.

Currently, growth rates are considered equal throughout the stand, however it is understood that growth rates will vary based largely on light availability/upper canopy shading and temperature. Future versions of the model would incorporate multi-layer dynamics to numerically capture these effects, as well as incorporate different growth functions for different plant life stages.

II.c.3.2. Preliminary Results. The Macroalgae Growth Model was applied to the West Coast Demonstration Area off Southern California as a test case (Figure 21). The monthly distribution of temperature and PAR follow expected seasonal trends with increases in both measures seen during the summer months (Figure 21A). As shown in Figures 16 to 19, seasonal changes in these measures influenced the suitability of each to sustain macroalgal growth. A map of relative growth rates (Figure 21B) indicates a general North-South gradient in growth rates, with values of 1 being the lowest growth rates and 8 being the highest. At this stage, the growth model is capable of producing estimations of total biomass, however, values are overly optimistic $\left(\sim 800 \mathrm{~g} \mathrm{C} / \mathrm{m}^{2} / \mathrm{yr}\right.$ or $4.1 \mathrm{~kg}$ of dry weight biomass), as additional biophysical parameters need to be included into the model (see section on Future Macroalgae Growth Model Enhancements). The coastal region of the mapped area corresponds with a region of greater influence from nutrient-rich upwelled waters (see Figure 13). Information such as this can be used to inform locating cultivation sites based on their ability to support growth of macroalgae. 


\section{A. Mean Monthly Sea Surface}

Temperature and PAR.
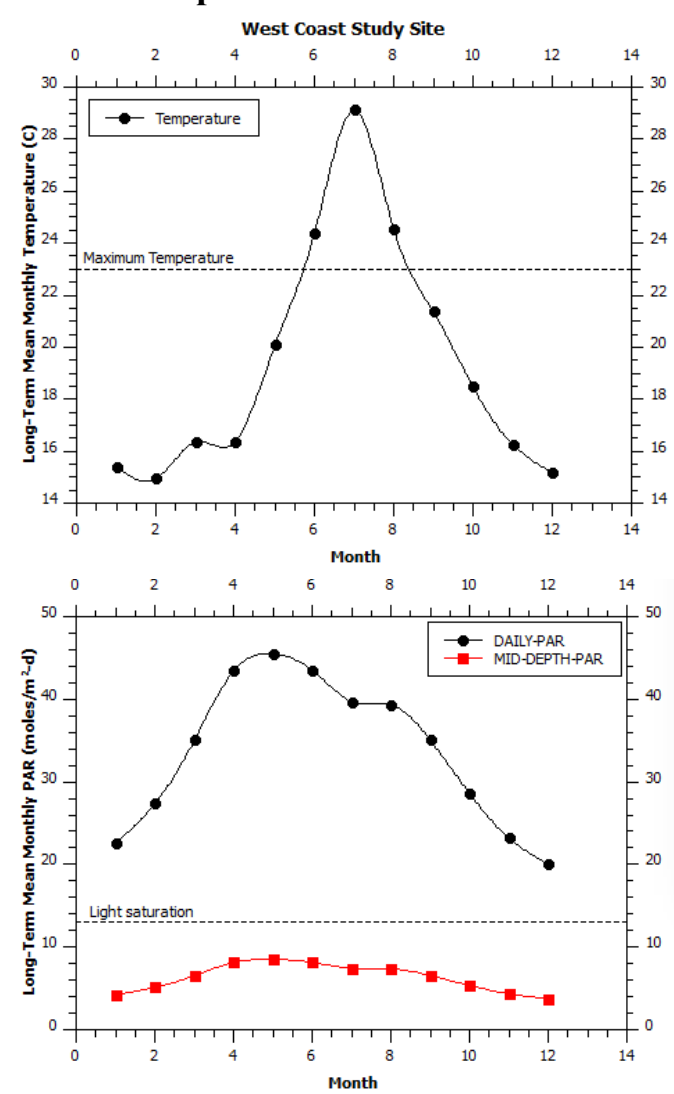

B. Map of relative growth rates.
Preliminary Relative Growth Rates

10-year Mean Annual (2001-2010)

West Coast Study Site

Figure 21. Application of the Macroalgae Growth Model to the West Coast Demonstration Area off the coast of Southern California to the western and southern limits of the EEZ. A) Mean monthly temperature and PAR measurements over the period 2001-2010. The effect of available PAR at the water surface and at a $6 \mathrm{~m}$ depth is illustrated and clearly indicates that light saturation limits are not achieved at this depth. B) Spatial data results of relative growth rates in the West Coast Demonstration Area off Southern California, where values of 1 are areas of lowest growth rates, and 8 are the highest. Warmer water temperatures in the southern portion of the study site are impeding growth and reporting lower overall biomass.

\section{II.c.4. Future Macroalgae Growth Model Enhancements}

Enhancements to the macroalgae growth model include continued refinement of the model and expansion of coverage from the West Coast Demonstration Area to the broader U.S. EEZ. The primary remotelysensed input model data for the EEZ are processed and ready for inclusion. The enhancements include the addition of the following features into the growth model:

- Depth-layered model calculations 
- Depth-temperature profile in $12 \mathrm{~m}$ water column

- Light attenuation through $12 \mathrm{~m}$ water column

- Inclusion of remotely-sensed turbidity into light-attenuation through the water column

- Variable starting depth

- Three-layer canopy shading and plant density

- Nutrient availability and uptake

- Inclusion of 4-growth stages / piecewise-linear growth rates

- Wave and current velocity disturbance

- Inclusion of estimated grazing losses

- Remotely-sensed levels of salinity and salinity influence on growth rates

- Optimization routines for growth duration, plant spacing, and time of year

- Biochemical feedstock composition for conversion

\section{II.d. Merged Macroalgae Resource MOdel For Optimal PRODUCtion AND Mitigation OF COMPETING USES}

To assess the production potential and optimize possible macroalgae cultivation sites in U.S. waters, the results of the constraints model and the macroalgae growth model need to be assessed at the same location. In this first year, we developed GIS-based models for Constraints and Macroalgae Growth. In the future, these results would be merged to determine realistic production estimates and identify key areas for potential investment (Figure 22).

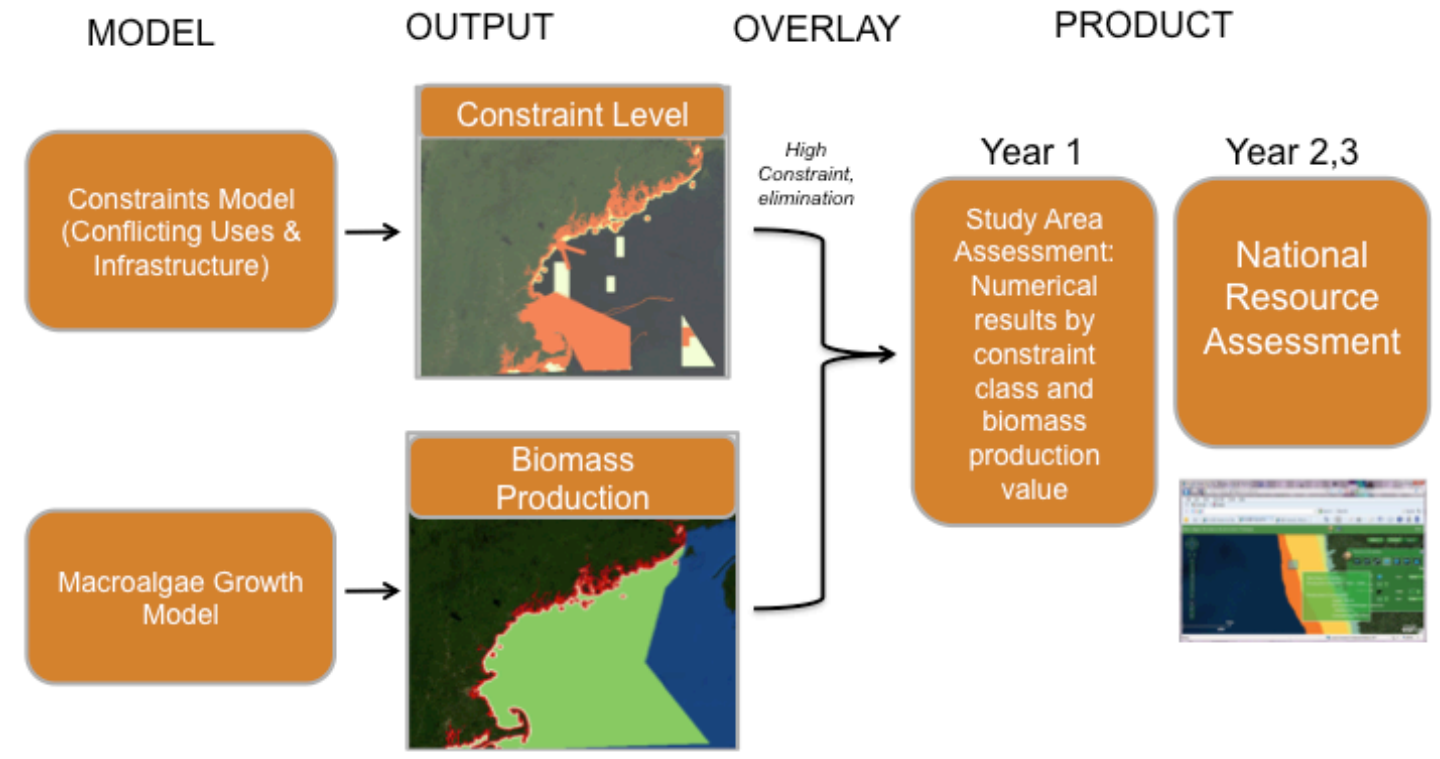

Pictures are lliustrative only

Figure 22. Spatial analysis of macroalgal production potential and conflicting use constraints.

Both model products are GIS-based raster datasets with regularly gridded values that represent constraint level and production potential across the U.S. EEZ. However, outputs are of different resolutions; the temporally varying growth model production estimate produces a computational grid cell value for every 
$16 \mathrm{~km}^{2}$ within the U.S. EEZ, whereas every cell in the constraints model represents a much smaller .0625 $\mathrm{km}^{2}$ area. By overlaying the production estimate and the constraint level, we believe an improved production estimate can be gained.

For a first level assessment, grid cells in the macroalgae growth model output would be subdivided at the same resolution as the constraint assessment. Each 6.25 ha cell that has been defined as having "High Constraint", would be used to mask out the corresponding area on the biomass production output leaving only projections for areas identified with "Low" and "Moderate" constraints. These production values remain as potential, as there is no actual macroalgae production facility. With this product, we wish to answer these basic questions in the first level assessment: what is the maximum national production, what is an optimized fractional production potential, and where are the areas located that would likely maximize this production. Potential areas for macroalgal production can be identified, and the corresponding production per unit-area estimates can be used to project production potential for facilities larger than one grid cell. Likewise, an optimization routine (e.g., Marxan decision support tool) can be run to find contiguous areas that meet production needs.

We would then investigate two modifications to assess how results may change and help identify critical uncertainties with projections. Our literature review identified two sources of uncertainty: A) How will offshore production and operation be impacted by the cost of operation, and B) How will variability in conditions impact production? The first modification is to develop a relationship between access/distance and costs of operation under different cost scenarios. The second is to evaluate different production levels under differing macroalgal genera, planting depths, spacing, fouling, and environmental conditions such as wave and storm action. Evaluating production values under different scenarios would result in a better understanding of the potential for macroalgae as a feedstock. 


\section{BIOFUELS INFRASTRUCTURE NEEDS AND INFORMATION GAPS}

\section{III.a. Background}

This document provides an assessment of land-based, port, and offshore infrastructure needs based on published and grey literature. Major information gaps and challenges encountered during this analysis include the following items:

- Poorly defined offshore algae culture infrastructure needs due to the immaturity of the industry in the U.S. Existing industrial offshore industries in the U.S. that can help inform infrastructure solutions.

- Working in the offshore marine environment is extremely challenging, equipment-intensive, and expensive.

- An important information gap is the type of vessels required based on cargo capacity and range, which would inform development of port selection criteria.

- Detailed cost analyses are needed to optimize macroalgae culture processes and infrastructure trade-offs.

- Socioeconomic and environmental analyses specific to macroalgae aquaculture are needed.

Unlike the offshore wind or the nearshore aquaculture industry, the offshore aquaculture industry has not yet coalesced on an optimal design for offshore infrastructure and best practices for the industry. A more in-depth analysis of infrastructure needs for offshore algae culture would be possible as offshore growth structures are optimized through design and testing.

The objective of the infrastructure assessment is to A) characterize the infrastructure requirements of a marine biomass industry associated with cultivation, harvest, transport and preliminary processing and B) document information gaps associated with infrastructure needs. The limited analysis about the potential for macroalgae as a feedstock for the biofuels industry has focused on biochemical analysis. There has been little or no consideration of a broader range of factors such as infrastructure needs, permitting requirements, supply chain considerations, or socioeconomic factors. Feasibility analysis (Roesijadi et al., 2010) suggests that the most promising areas for cultivation in the U.S. are offshore (as opposed to nearshore coastal waters or bays), necessitating larger economies of scale and mechanized harvesting.

The current macroalgae industry is dominated by production of food products additives, pharmaceutical, and a few other uses. Ten times the amount (by wet weight) of algae is grown in aquaculture operations than wild harvest (Roesijadi et al., 2010). Over $90 \%$ of seaweed species that are currently cultured are among one of four genera: Laminaria (also Saccharina), Porphyra, Gracilaria, and Undaria (Roesijadi et al., 2008). China supplies the vast majority of macroalgae produced through aquaculture (Roesijadi et al. 2010).

\section{III.b. Cultivation Site Location}

Algal cultivation sites can be located nearshore, offshore, or in land-based ponds. Nearshore refers to farm operations in which growth structures are deployed as arrays in subtidal areas in close proximity to shorelines. Nearshore refers to habitats of sufficiently shallow depth to enable seaweeds to attach and grow or provide a sheltered environment for aquaculture operations. Offshore refers to operations in deep 
water requiring growth structures that are tethered to ocean bottoms or deployed as floating arrays requiring positioning devices. For the context of this report, "offshore" or "open ocean" growing conditions refers to growing seaweed in waters that are generally too deep for even giant kelp to survive on their own and that are free from the direct influence of land. We make no distinction between "offshore" and "open ocean" although others do (Upton and Buck, 2010). Land-based ponds need to have seawater and nutrients delivered to them and benefit from being in close proximity to natural sources of seawater. Co-locating aquaculture facilities with compatible uses should also be explored (Buck et al., 2004).

\section{III.c. Macroalgae Production}

In the 1970s and early 1980s, the Marine Biomass Program (Bird and Benson, 1987) tested offshore growth structures off the coast of Southern California ${ }^{1}$. While the structures supported kelp growth, they were not seaworthy enough to withstand ocean conditions and the kelp attachment was not secure enough to produce results. The engineering challenges associated with achieving seaworthiness were not addressed before the program was discontinued. Several attempts to cultivate macroalgae in offshore/nearshore structures were attempted in the late 1970s/1980s in North America, but none prompted the commercial cultivation of algae (Bird and Benson, 1987).

However, with renewed interest in algal biofuels, technological and engineering advances of the last three decades are being considered for application to this new industry. A prototype for open ocean cultivation was successfully tested in the North Sea (Buck and Buchholz, 2004; Buck and Buchholz, 2005). Several other growth platforms have been developed and tested to some degree, but none have developed into a commercial culture operation from which we can pull information about infrastructure requirements. A handful of companies are currently exploring nearshore production of macroalgae for fuels, primarily China, Japan, and Chile. Land-based pond culture is currently focused on macroalgae production for specialty markets (Roesijadi et al., 2010).

In this report, we summarize the infrastructure requirements, both offshore and land-based, for different phases of macroalgae cultivation in the nearshore and offshore marine environments (Figure 23). We also discuss the land-based infrastructure needed to support marine cultivation. Cultivation of macroalgae in land-based ponds is not addressed in this report, but would be expected to include challenges analogous with that experienced with microalgae siting and production and include coastal land availability, seawater pipeline routing, clean pumping sources, pond blowdown, pond wastewater and salt management, nutrient management, and environmental regulation and policy. Harvesting natural stocks is not considered because the environmental impacts could outweigh benefits at scales required to meet national biomass needs for biofuel production. Finally, we highlight critical information about infrastructure requirements needed to fully evaluate the feasibility of development of a macroalgae biofuels industry.

\footnotetext{
${ }^{1}$ In 1973 a 3 ha grid structure was deployed but lost the first winter. In 1981 two plots of 0.2 ha grid structures were deployed and survived long enough to support cultivation of Macrocystis.
} 


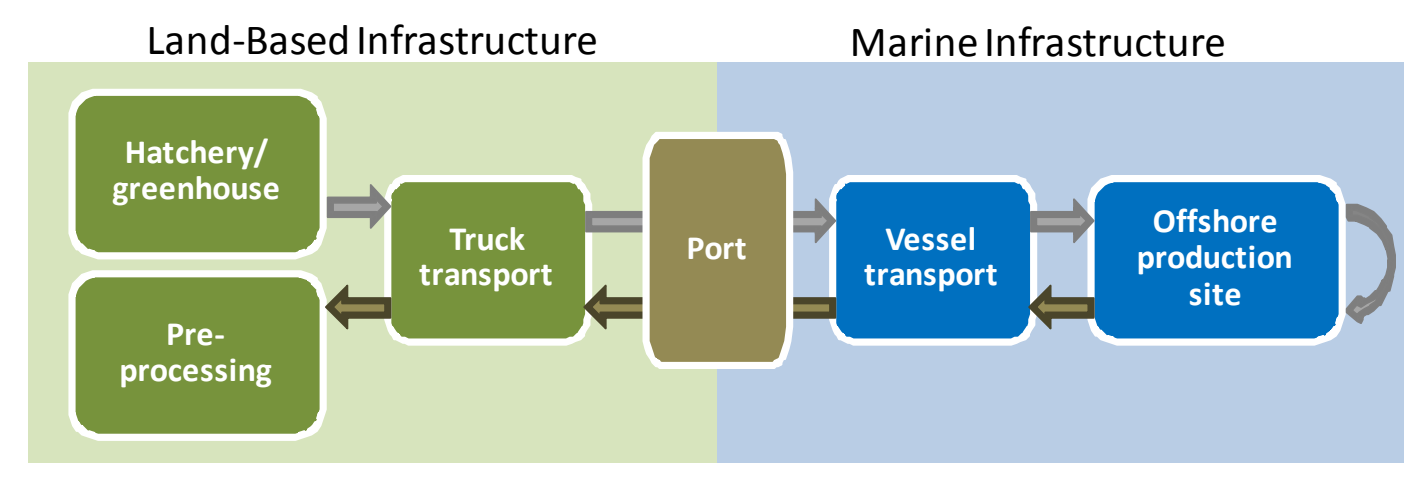

Figure 23. Marine biofuels infrastructure requirements for commercial production.

We reviewed commercial websites and published reports, as well as other available published literature, to summarize infrastructure needs and glean information gaps.

\section{III.d. Infrastructure Associated with Phases of Development}

Phases of development include cultivation of seeds and rearing of plantlets, deployment offshore and rearing of plants, harvest, and processing. Processing is divided into pre-processing, minimal processing for cleaning, dewatering, desalination, and final-processing and conversion of the algae into biofuels. Distribution and consumption are not covered here.

Expected infrastructure needs for onshore cultivation and rearing, offshore deployment and rearing, harvesting, and processing can be defined as follows. We discuss each stage and associated land-based or offshore infrastructure.

- Land-based infrastructure

- Greenhouses/hatcheries - cultivation of seeds and rearing of plantlets attached to growing substrate

- Packing and transport - transport by truck to/from port or direct loading/unloading of plantlets onto vessels

- Pre-processing facility - drying, packaging for transport

- Post-processing facility - final drying, extracting alcohols

- Port infrastructure

- Vessel berth

- Loading and receiving - cranes, ramps, storage

- Offshore infrastructure

- Floating structures - buoyancy devices, navigational markers

- Anchors/moorings - hold shape and in place

- Vessels - deployment, maintenance, harvest, transport between port and growing site

\section{III.e. Cultivation of Seeds and Rearing of Plantlets}

Understanding the life cycle and promising macroalgal species has allowed the propagation of algae with artificially-produced sporelings. Typically, macroalgal sporophytes are grown in greenhouses and then attached to substrates. They are then reared to plantlet size and transplanted to coastal farms where they are attached to moored floating structures to grow to harvest size (Roesijadi et al., 2010). Buck and Buchholz (2004) describe growing cultured sporophytes for a period of two months using artificial 
sunlight. They also describe increased tissue strength in the holdfast and stipe when brood stocks are exposed to $>1 \mathrm{~m} \mathrm{~s}^{-1}$ velocities. The sporophytes were attached to $6 \mathrm{~mm}$ polypropylene line and arranged along frames that were rotated every second day. FAO (2011) describe growing Laminaria japonica to include control of light intensity using roof curtains, seawater temperature control for growth rate optimization, chemical fertilizers (nitrate and phosphate), and removal of unwanted algae. Considering these descriptions, the infrastructure needed includes enclosed indoor workspace large enough to accommodate multiple tanks for cultivation and rearing. Size of land-based facilities depends on the scale of operation. Infrastructure requirements include the ability to regulate water temperature and sunlight exposure; fertilization, seawater circulation, and purification; and area for preparing plantlets for transport.

\section{III.f. Transportation to Offshore Growing Site}

Transportation at this stage involves trucking plantlets already attached to a growth substrate to a port facility and loading plantlets onto a vessel for transportation to the offshore culture site. Land-based infrastructure requirements for highway or rail transport include hauling vehicle and loading/unloading capacity, while marine infrastructure requirements include vessel for hauling, deploying, and retrieving kelp, and vessel berths.

\section{III.g. Offshore Deployment}

Experience in practical offshore algae cultivation has been limited to a few test-scale deployments over the past 30 years. The most noteworthy of these are summarized below (Table 5). Useful analogies for land-based infrastructure needs are available from Asia, but, beyond land-based greenhouses, these operations generally transfer plantlets to only shallow nearshore or coastal waters. Harvesting is also primarily done by hand, which could not support commercial-scale macroalgae culture operations in the offshore environment. A better analogue for offshore macroalgae operations is the experience, to date, with offshore finfish aquaculture. Commercial open ocean finfish aquaculture facilities operating in U.S. state/territorial waters include Cates International, Inc., which cultivates moi (Pacific threadfin) off Hawaii, and Snapperfarms, Inc., which cultivates cobia near Puerto Rico. In September 2005, Kona Blue Water Farms of Hawaii celebrated its first harvest of kahala reared in deepwater pens in state waters. While some aspects of infrastructure for offshore finfish culture may be applicable to macroalgae cultivation (i.e., anchoring systems, durability, mitigation for navigational impacts, mechanical maintenance), the economic and environmental impacts of macroalgae aquaculture differ significantly from that of finfish aquaculture. However, co-location with these types of facilities is a consideration in integrated aquaculture. 
Table 5. Offshore Algae Culture Experience.

\begin{tabular}{|c|c|c|c|}
\hline $\begin{array}{l}\text { Region or } \\
\text { country }\end{array}$ & Project name & $\begin{array}{l}\text { Distance from shore, } \\
\text { depth, area }\end{array}$ & Notes, references \\
\hline \multirow[t]{3}{*}{ U.S } & Marine Farm Project & $\begin{array}{l}1 \mathrm{~km} \text { offshore in } 50-150 \\
\mathrm{~m} \text { depths covering an } \\
\text { area } 600 \mathrm{~m} \times 600 \mathrm{~m}\end{array}$ & $\begin{array}{l}\text { - Precursor to the Marine } \\
\text { Biomass Program } \\
\text { - North (1987) }\end{array}$ \\
\hline & $\begin{array}{l}\text { Marine Biomass Program, } \\
\text { Offshore Test Platform } \\
\text { (OSTP) aka QAM }\end{array}$ & one quarter acre in size & $\begin{array}{l}\text { - Included } 450 \text { m upwelling } \\
\text { pipe, resembled upside- } \\
\text { down umbrella } \\
\text { - Bird and Benson (1987) }\end{array}$ \\
\hline & Ocean Spar System & & $\begin{array}{l}\text { - Another design is the } \\
\text { "Sea-station } \\
\text { - Loverich and Goudey } \\
\text { (1996); Lisac (1997); }\end{array}$ \\
\hline Mediterranean & $\begin{array}{l}\text { Tension Leg System } \\
\text { consists of a floating, } \\
\text { tethered net }\end{array}$ & Undefined & - Lisac $(1996 ; 1997)$ \\
\hline North Sea & $\begin{array}{l}\text { The offshore ring (and } \\
\text { other systems) }\end{array}$ & $\begin{array}{l}12-14 \mathrm{~m} \text { depth, } 3.5 \mathrm{~nm} \\
\text { offshore }\end{array}$ & - Buck and Buchholz (2004) \\
\hline Chile & $\begin{array}{l}\text { Testing cultivation of } \\
\text { Macrocystis pyrifera }\end{array}$ & Undefined & $\begin{array}{l}\text { Macchiavello et al. } \\
\text { (2010); Gutierrez et al. } \\
\text { (2006) }\end{array}$ \\
\hline
\end{tabular}

Starting in the 1970s, the U.S. funded several research efforts into cultivation of seaweed as a source of energy (Roesijadi et al., 2008). The Marine Farm Project was the first tethered offshore cultivation test project. Engineering and productivity analyses arrived at conflicting conclusions about the feasibility of mass offshore cultivation, but generated enough interest to garner large investments from the U.S. Department of Energy into the Marine Biomass Program starting in the late 1970s. The Marine Biomass Program built on previous research and development into offshore seaweed culture and resulted in two consecutive offshore cultivation trials using the kelp Macrocystis pyrifera. The program was challenged by harsh winter storms and lower than expected growth rates, but it did demonstrate the possibility of growing macroalgae on an artificial net structure offshore. However, the productivity of the system could not be determined in the field and many questions remain about the practicality of an offshore farm. Economists for the Marine Biomass Program identified an area of 2,600 ha to economically grow Macrocystis for energy biomass in offshore farms off Southern California and a need for by- and coproducts such as animal feedstocks to produce additional revenue (Bird, 1987). This assumes the additional infrastructure of a deepwater (up to $500 \mathrm{~m}$ ) upwelling pipe to deliver nutrients to growing plants. This design was tested as part of the Marine Biomass Program.

For technological reasons, possible shelter from storms, and accessibility for installation, maintenance, and harvest, most algae culture currently occurs in nearshore areas. However, limitations on nearshore space, viewshed conflicts, and conflicts with other nearshore users have generated interest in offshore areas where larger-scale operations are possible. 
Offshore culture infrastructure consists of floating structures that either drift in the current or are anchored or otherwise held in place. There are several promising designs, but most have yet to be tested in largescale operations. Fixed-location structures require anchors and mooring lines or could be held in place by dynamic positioning. Drifting structures (not yet tested) avoid the need for anchors, but controlling growing conditions becomes more difficult and fertilization or pumping of nutrient rich water may be necessary. Floatation devices on the structures either provide fixed buoyancy or allow buoyancy to be adjusted to avoid storms and to optimize light and nutrients. Offshore structures would need to be equipped with an Automatic Identification System (AIS), visual navigational aids (colorful, tall, and lighted), and likely GPS tracking systems.

Fixed-location structures, held in place with anchors and mooring lines, have been developed. These structures have been deployed in near-coastal areas (1 km from shore). One exception is structures installed in the North Sea $3.5 \mathrm{~nm}$ from shore $(6.5 \mathrm{~km}$ ) (Buck et al., 2004). Buck et al. (2004) tested four different cultivation systems including longline ladder (tandem longline), grid, and ring-shaped and found the ring-shaped configuration to be superior for ease of deploying and retrieving the array and for withstanding harsh conditions. Concrete blocks of 2.5-4.5 ton were used to moor the floating array. Ladder and grid constructions were oriented parallel to the tidal current. The floating array used buoys or fenders connected to the array for flotation. Aizawa et al. (2007) envision, but have not developed or tested, a facility located in coastal waters shallower than 500 meters and offshore in water depths between 500-3,000 meters. Offshore "sea kites" would be used $1.5 \mathrm{~km}$ length by $1 \mathrm{~km}$ width. Single point, deepwater moorings would be used, with ropes or nets for attachment of algae. In Japan, a design for a marine farm of $41 \mathrm{~km}^{2}$ area, $5 \mathrm{~km}$ wide and $8 \mathrm{~km}$ long, has been proposed at a distance of $8 \mathrm{~km}$ from the coast and estimated to produce up to 1 million wet tonnes of Laminaria japonica (Yokoyama et al., 2007).

\section{III.h. Harvest}

Manual harvesting of cultured macroalgae is common in nearshore operations; however, large offshore macroalgal farms would have to depend on mechanized harvesting methods. Depending on the species cultivated and attachment method used, harvest may involve mowing (leaving the growth structure in place) or recovery of algae and the growth substrate for separation on land (Ugarte and Sharp, 2001). Harvesting would likely require developing a reaping vessel (Aizawa et al., 2007), although vessels equipped with A-frames such as trawling or long-line fishing vessels could possibly be adapted to recover algae and growth substrates.

At smaller scales, Buck and Buchholz (2004) describe harvest at sea using divers or boat-based cranes from small boats. The ring culture configuration was towed to shore and lifted on land by cranes. This would be feasible for nearshore operations where towing to shore of the growth structure would not be expected to dislodge algae.

\section{III.i. Transportation to Shore}

Harvested algae would likely be transported ashore in barges or vessels holds for receiving and loading onto land-transportation (trucks or trains) for pre- and or final processing. In the event that a processing facility could be constructed shore-side or adapted from existing waterfront infrastructure, land-based transportation may not be necessary. Similarly, there may not be a need for transportation from the site of preprocessing and final processing if these two functions are co-located. 


\section{III.j. Preprocessing}

Preprocessing involves removing debris by washing, milling to reduce the size and increase uniformity, and dewatering to improve shelf life and decrease costs associated with transportation. The extent of debris removal depends on the growth method, but generally suspended cultivation would require less debris removal. Preprocessing to date occurs on land, but could theoretically occur at sea with specialty vessels.

\section{III.k. Land Transportation, Final Processing, Packing, and Distribution}

Highway or rail transportation would be required to deliver preprocessed macroalgae to a processing facility. Final processing of macroalgae involves conversion of carbohydrate feedstocks for fuel production, anaerobic digestion being the most developed pathway (Hennenberg et al., 2009). Processed fuel would be delivered to distributers.

\section{III.I. Information Gaps and Challenges}

Offshore algae culture infrastructure needs are not well defined due to the immaturity of the industry in the U.S. and the non-transferability of much of the design and technological solutions developed in other countries. Existing industrial offshore industries that can help inform infrastructure solutions for the U.S. include petroleum extraction, liquid natural gas ports, commercial shipping and transportation, and commercial fishing. In addition, harvest of renewable ocean energy from waves, tides, and offshore wind are emerging industries in the U.S. with distinct infrastructure requirements (Barr, 2010; Tetra Tech EC et al., 2010). The U.S. Department of Energy is currently investing in research and development to understanding the port, manufacturing, and vessel infrastructure needed to support offshore wind installation and operation. ${ }^{2}$ On the other hand, European countries have over 20 years of experience with offshore wind and European governments and companies have invested substantially in manufacturing, port, and vessel capabilities to support this industry.

Unlike the offshore wind or the nearshore aquaculture industry, the offshore aquaculture industry has not yet coalesced on an optimal design for offshore infrastructure. The variety of offshore aquaculture models developed and tested (Table 5) underscores this point and makes it difficult to evaluate the technologies and facilities needed to build, transport, and assemble the offshore components. For example, at-sea operational conditions, volume and weight of material transported, water depth, distance offshore, and mechanism for deployment and recovery of macroalgae are key factors for determining vessel suitability. These factors as well as berth length, load/offload, and onshore preprocessing needs help determine port requirements. An example of the detailed analysis possible for a more mature industry with agreed-upon technology, in this case offshore wind, is provided by Tetra Tech EC et al. (2010). A more in-depth analysis of infrastructure needs for offshore algae culture would be possible as offshore growth structures are optimized through design and testing.

Working in the offshore marine environment is extremely challenging and expensive. Storms offshore can be severe and working conditions are dangerous and technically demanding. Federal regulations designed to protect the U.S. maritime industry, offshore workers, and the marine environment may limit certain approaches to offshore algae cultivation and algae harvest transportation. For example, section 27 of the Merchant Marine Act of 1920, also known as the Jones Act, stipulates transportation of waterborne cargo

\footnotetext{
${ }^{2}$ For more details, see Financial Assistance Finding Opportunity Announcement number DE-FOA-0000414 released on February 7, 2011.
} 
between U.S. ports be by U.S. flagged vessels constructed in the U.S., owned by U.S. citizens, and crewed by U.S. citizens or permanent residents. Jones Act regulations have raised concerns with offshore wind developers because the U.S. lacks needed specialty vessels to support the industry and the Act precludes any European-built specialty vessels from operating in U.S. waters without a waiver. Depending on the vessel requirements, the availability of U.S. flagged vessels capable of algae harvest and transportation to and from offshore growing sites may present a significant barrier to development of the industry. Therefore, an important information gap is the type of vessels required based on cargo capacity and range. This information would be determined by the species of algae grown, the location of the offshore growing site, and the harvest method. Siting and vessel size will strongly influence port selection. While several offshore culture deployments have tested a range of species, sites, and harvest methods, technological or economic factors have yet to determine best practices.

Uncertainty surrounding economic opportunities and limitations is a significant obstacle in designing offshore macroalgae aquaculture systems from culture to final processing. Preliminary economic assessments (e.g., Roesijadi et al., 2008) provide an essential foundation onto which must be built more detailed cost analyses that can inform optimization of the macroalgae culture process and infrastructure. Socioeconomic and environmental analyses specific to macroalgae aquaculture are also conspicuously lacking. Analyses of aquaculture focus on issues that almost exclusively apply to finfish aquaculture including feed additives, spread of disease, waste generation and algal blooms, impact of fish escapes on wild populations, using wild fish to feed farmed fish, the introduction of genetically modified or nonnative organisms, displacement of wild caught fishing livelihoods through economic competition or closed areas, and commercialization of the offshore environment (Pew Oceans Commission, 2003; U.S. Commission on Ocean Policy, 2004).

Finally, current U.S. law does not provide a clear mechanism for permitting commercial aquaculture operations in federal waters (3-200 miles offshore), and this regulatory uncertainty is a major barrier to development of the industry (U.S. Commission on Ocean Policy 2004 and Pew Oceans Commission 2003). In recent years, several bills have been introduced in Congress to develop regulatory pathways to offshore aquaculture, but none has become law (Upton and Buck, 2010). Several offshore finfish aquaculture demonstration projects in state/territorial waters can provide lessons-learned regarding, not only permitting challenges and solutions, but also technical approaches to mooring, array/net maintenance, and construction. 


\section{PERMITTING REQUIREMENTS FOR MARINE BIOFUELS PRODUCTION}

\section{IV.a. Background}

Any entity pursuing commercial-scale macroalgae culture in offshore waters of the U.S. would be required to work with government agencies to minimize negative project impacts and secure necessary operating permits. Multiple federal, state, and local laws regulate development and industrial activities on land and in the marine environment. In order to facilitate compliance with multiple legal requirements, a permitting pathway may be established to coordinate regulatory review and a lead agency may be designated by Congress. Although it is a national policy to encourage the development of aquaculture in U.S. waters ${ }^{3}$, uncertainty regarding exclusive spatial access rights has hampered the development of the industry. The current regulatory regime has been characterized as complex, inconsistent, and overlapping in policies and regulations and managed by numerous state and federal agencies (Pew Oceans Commission, 2003; U.S. Commission on Ocean Policy, 2004; Upton and Buck, 2010).

The purpose of this section is to discuss the type of local, state, and federal requirements that pertain to siting land-based facilities and nearshore/offshore culture operations.

\section{IV.b. National Aquaculture Policy}

Federal laws with a focus on aquaculture (e.g., The National Aquaculture Act of 1980, The National Aquaculture Improvement Act of 1985, and Executive Order 12039 dated February 24, 1978) articulate a national policy encouraging the development of aquaculture and task working groups with addressing permitting and other barriers, including those limiting offshore aquaculture development. Yet, little progress has been made to develop a domestic offshore aquaculture industry in the past 40 years. Most national legislation is targeted towards finfish aquaculture, although culture of aquatic plants is generally included in the definition of aquaculture.

In the early 2000s, two major national ocean policy reviews took place. In 2003, the Pew Ocean Commission released their report, America's Living Oceans: Charting a Course for Sea Change, and, in 2004, the U.S. Commission on Ocean Policy released their report, An Ocean Blueprint for the $21^{\text {st }}$ Century. Both commissions reached similar conclusions regarding marine aquaculture, which are summarized below, and recommended several policy and administrative changes needed to promote the sustainable development of aquaculture:

- Designate a lead agency (NOAA) to oversee the industry, develop offshore aquaculture national policies, and create a comprehensive permitting, leasing, and regulatory program.

- Increase knowledge and innovation through expanded research, technology development, and training opportunities.

- Collaborate with international entities to establish and encourage international compliance with standards for sustainable aquaculture (U.S. Commission on Ocean Policy 2004, Pew Oceans Commission 2003).

In response to the findings of these two commissions and increasing interest in commercial, offshore aquaculture, NOAA developed the National Offshore Aquaculture Act, which was introduced in the $109^{\text {th }}$

\footnotetext{
${ }^{3}$ See the National Aquaculture Act of September 26, 1980, Public Law 96-362, 94 Stat. 1198, 16 U.S.C. 2801 , et seq.
} 
and $110^{\text {th }}$ Congress at the request of the Bush Administration. The Act, which has not become law, designates NOAA as the lead federal permitting agency and tasks NOAA to develop a regulatory pathway for offshore aquaculture. Wild-caught fisheries interests continue to voice concerns about development of this industry, and environmental interests have also expressed concerned about the Act's unspecified approach to addressing individual and cumulative environmental impacts. In 2007, NOAA developed a 10-Year Plan for its aquaculture program, which involves developing a comprehensive regulatory program within NOAA. Draft National Aquaculture Policies have recently been published for public comment. In spite of NOAA's leadership in responding to the need for a permitting process, some question the appropriateness of using NOAA's existing authority and Fishery Management Plans to manage aquaculture (Upton and Buck, 2010). ${ }^{4}$ As a result, the regulatory process remains unclear.

To date, the debate around aquaculture has focused almost exclusively on finfish aquaculture and the associated environmental and socioeconomic concerns such as feed additives, spread of disease, waste generation and algal blooms, impact of fish escapes on wild populations, using wild fish to feed farmed fish, the introduction of genetically modified or non-native organisms, displacement of wild caught fishing livelihoods through economic competition or closed areas, and commercialization of the offshore environment. Assuming no fertilization is required and native species are used, closed areas and commercialization of the offshore environment are the only concerns that apply to offshore macroalgae culture. However, there has been no distinction in legislation or public debates between finfish aquaculture and algae aquaculture on these points.

For more detail on the history of national policy of offshore aquaculture, see Firestone et al. (2004) and Upton and Buck (2010).

\section{IV.c. Permitting Requirements for Offshore Macroalgal Production}

Permitting requirements for onshore and nearshore/offshore culture of macroalgae for biofuels would likely be numerous and arduous. This is supported by several examples of finfish aquaculture within state waters (there have been limited tests of facilities in federal waters and there are no commercial aquaculture facilities in federal waters). ${ }^{5}$ Land use regulations and building codes govern siting of landbased greenhouses used to culture macroalgae seeds and grow plantlets. If greenhouses are located in areas near the shoreline, additional regulations may apply to protect the marine environment and neighboring properties. These requirements may be implemented by a state, county, city or other local jurisdiction and vary by coastal state. Onshore aquaculture activities would likely be treated similarly to other industrial and agricultural uses; there is a long and well-documented history of permitting such facilities. However, the regulatory pathway for offshore culture and harvest operations is much less clear. This is primarily due to limited experience on the part of regulatory agencies and developers, but also concern about interference with existing ocean uses, human safety, and sensitive or commercially

\footnotetext{
${ }^{4}$ Other recent legislative activity includes the National Sustainable Aquaculture Act of 2009 introduced by Congresswoman Lois Capps (D-CA) to create a comprehensive regulatory and permitting system and the Research in Aquaculture Opportunity and Responsibility Act of 2010 introduced by Senator David Vitter (R-LA). Both bills take a more precautionary approach to developing aquaculture in U.S. waters based on concerns about negative environmental and socio-economic impacts.

${ }^{5}$ There are currently four commercial open ocean aquaculture facilities operating in U.S. state/territorial waters. Cates International, Inc., cultivates moi (Pacific threadfin) near Hawaii, and Snapperfarms, Inc., cultivates cobia (ling) near Puerto Rico. In September 2005, Kona Blue Water Farms of Hawaii celebrated its first harvest of kahala reared in deepwater pens in state waters. In 2007, A. E. Lang Fisheries began cultivating blue mussels off the coast of New Hampshire in collaboration with the University of New Hampshire's Atlantic Marine Aquaculture Center (Upton and Buck 2010).
} 
valuable marine habitats and species. Ocean resources are often viewed as expansive and plentiful and, while many are, ocean resources have been heavily impacted by human uses including fishing, shipping activities, and waste disposal. Unlike the terrestrial environment, in the ocean, it is nearly impossible to contain wastes generated from industrial operations. Human safety is also a much greater challenge in the marine environment, especially in the open ocean.

Regulations applicable to commercial offshore macroalgae cultivation govern site leasing on submerged lands, water quality, navigation and safety, national security, and marine habitat and species. In the past decade, the need for improved, spatially-explicit management of ocean uses has emerged from increasing competition for desirable ocean space among existing and new ocean users. Coastal and Marine Spatial Planning is a process that identifies and spatially catalogues existing and new ocean uses and prioritizes activities in certain location. The process is led by multi-state regional planning bodies and overseen by the National Ocean Council. ${ }^{6}$ Several states have recently undertaken spatial planning activities for their state waters including Massachusetts, Rhode Island, California, and Oregon. Consideration of existing and new ocean uses when siting offshore aquaculture facilities is essential, but to date statutory mechanisms only provided a use-by-use approach, making comprehensive spatial planning difficult. In addition, while several federal agencies have jurisdiction over various impacts associated with offshore aquaculture, no agency has the express authority to lease federal ocean space for aquaculture (Firestone et al., 2004; Upton and Buck, 2010).

All subtidal lands are publically owned; therefore a site lease must be obtained from the public trust agency. In state waters (0-3 nautical miles offshore for most states $\left.{ }^{7}\right)$, the trust agency is generally a state natural resources agency. In federal waters (3-200 nautical miles offshore), the Bureau of Ocean Energy Management, Regulation, and Enforcement (BOEMRE) has authority to lease land for oil and gas exploitation on the Outer Continental Shelf (OCS) through the Outer Continental Lands Act, but this authority does not expressly include aquaculture (Firestone et al., 2004). In 2008, Minerals Management Service (MMS, now BOEMRE) announced a Record of Decision to establish an alternative energy and alternative use (AEAU) program, which allows MMS to authorize individual projects on a case-by-case basis for alternative energy or alternative use of existing structures on the OCS (i.e. oil and gas platforms). ${ }^{8}$ Although aquaculture is identified as one of the potential alternative uses of existing platforms, it is still not clear whether BOEMRE could issue a lease for an aquaculture operation not based on an existing structure. For macroalgae at least, growing conditions are not optimal in the Gulf of Mexico where most platforms currently exist.

In addition to BOEMRE, other permit granting agencies include the U.S. Army Corps of Engineers (USACE) for placing a structure in navigable waters of the U.S., the Environmental Protection Agency (EPA) for regulation of discharge from a facility, and NOAA, which regulates marine species and habitats and ocean fishing and, also, oversees the Coastal Zone Management Program (Figure 24). The USACE and the U.S. Coast Guard (USCG) have jurisdiction over navigation and safety issues for any facility located in either state or federal water. Also in both state and federal waters, NOAA and U.S. Fish and Wildlife Service (USFWS) (for migratory birds only) are responsible for species and habitat protection, however, state natural resource agencies also have jurisdiction in state waters. In many states, the EPA has delegated Clean Water Act compliance authority to a state agency. In those cases, the EPA would only engage in permitting for a facility in federal waters.

\footnotetext{
${ }^{6}$ For more information about CMSP, please visit the Council on Environmental Quality's website http://www.whitehouse.gov/administration/eop/ceq/initiatives/oceans.

${ }^{7}$ Florida and Texas state ownership extends 3 marine leagues, approximately 10 nautical miles.

${ }^{8}$ Federal Register vol. 73, no. 7, January 10, 2008.
} 


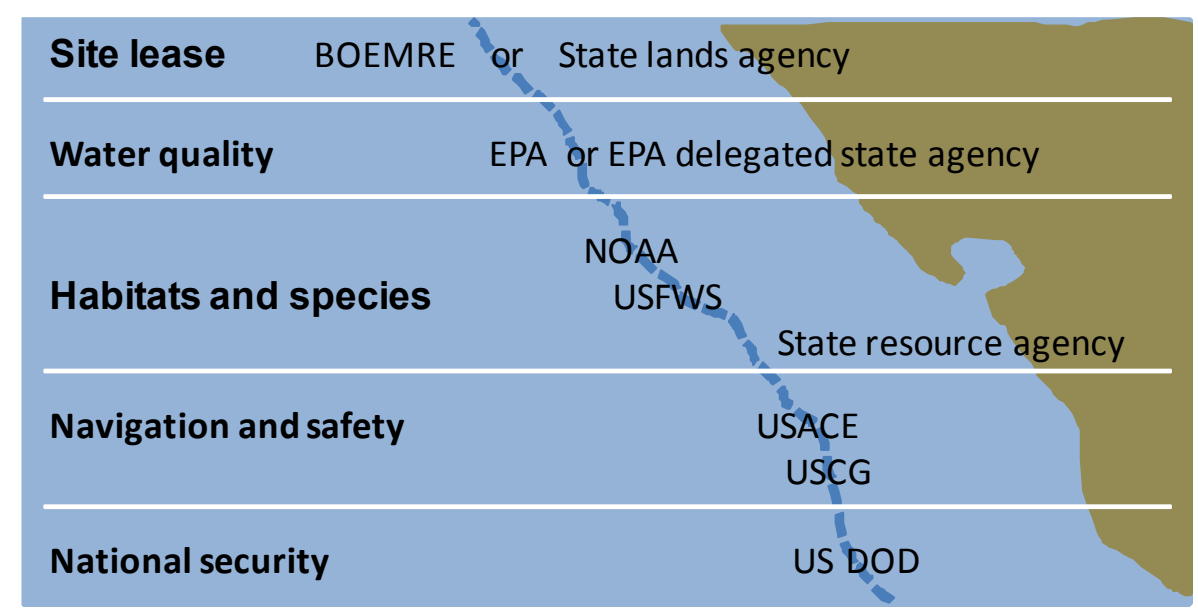

Figure 24. Summarized view of consenting agencies by major issue area for projects in federal versus state waters. The hashed blue line represents the limit of state waters (generally 3 nautical miles offshore). Federal agencies straddling the hashed line have consenting authority in both federal and state waters.

Finally, for projects located in federal waters offshore of states with an approved Coastal Zone Management Program, ${ }^{9}$ states enjoy the authority to determine if an aquaculture facility is consistent with their federally-approved state program. At least two states have banned salmon aquaculture or finfish aquaculture broadly (California and Alaska, respectively) in state waters. In these cases, macroalgae culture may or may not be included in this prohibition depending on the scope of motivating concerns. Table 1 lists relevant laws and the responsible federal agency or agencies.

The National Environmental Policy Act (NEPA) applies to federal actions that could have an effect on the environment and ensures that environmental impacts and public concerns are considered in federal decisions. Unlike the other statutes in Table 6, NEPA is strictly procedural, meaning that it does not dictate specific outcomes or standards, but requires a strict process of investigating and considering impacts. The lead federal agency is responsible for NEPA compliance. In the current regulatory process, the USACE would likely be the lead agency through authority granted by the Rivers and Harbors Act, Outer Continental Lands Act, and Clean Water Act (dredge and fill permit). National Historic Preservation Act (NHPA) Section 106 review is often incorporated as part of the NEPA process.

Federal regulations currently governing offshore macroalgae culture were not designed to address this unique ocean use. The permitting process is not well suited to offshore macroalgae aquaculture and it is likely that, should macroalgae culture develop into a commercial industry in the U.S., the permitting process would be improved. The recent attempt by the Bush Administration to develop such a process, The National Aquaculture Act of 2007, has yet to pass Congress.

\footnotetext{
${ }^{9}$ Currently 34 states and U.S. territories have approved Coastal Management Programs protecting more than 99 percent of the nation's 95,331 miles of ocean and Great Lakes coastline (http://coastalmanagement.noaa.gov/programs/czm.html)
} 
Table 6. Federal authorities governing offshore macroalgal aquaculture.

\begin{tabular}{|c|c|c|c|c|}
\hline Potential impact or issue & Permit or approval & $\begin{array}{l}\text { Statutory } \\
\text { authority }\end{array}$ & $\begin{array}{l}\text { Regulatory agency (other agencies } \\
\text { involved) }\end{array}$ & $\begin{array}{l}\text { Geographic } \\
\text { scope of statute }\end{array}$ \\
\hline Endangered species & ESA $§ 7$ Permit & $\begin{array}{l}\text { Endangered } \\
\text { Species Act }\end{array}$ & $\begin{array}{l}\text { NOAA, USFWS (USACE, USCG, } \\
\text { NOAA) }\end{array}$ & $\begin{array}{l}\text { Federal and state } \\
\text { waters, on shore }\end{array}$ \\
\hline $\begin{array}{l}\text { Marine mammal } \\
\text { disturbance or harm }\end{array}$ & $\begin{array}{l}\text { Marine mammal consultation. } \\
\text { May require Incidental } \\
\text { Harassment Authorization or } \\
\text { Letter of Authorization }\end{array}$ & $\begin{array}{l}\text { Marine Mammal } \\
\text { Protection Act }\end{array}$ & $\begin{array}{l}\text { NOAA (USFWS for walrus and polar } \\
\text { bear) }\end{array}$ & $\begin{array}{l}\text { Federal and state } \\
\text { waters, on shore }\end{array}$ \\
\hline Marine fish & $\begin{array}{l}\text { Essential Fish Habitat } \\
\text { Assessment }\end{array}$ & MSA & $\begin{array}{l}\text { NOAA (Regional Fisheries } \\
\text { Management Councils) }\end{array}$ & $\begin{array}{l}\text { Federal and state } \\
\text { waters }\end{array}$ \\
\hline Marine fish & Fishery Management Plans & MSA & $\begin{array}{l}\text { Regional Fishery Management } \\
\text { Councils }\end{array}$ & $\begin{array}{l}\text { Federal and state } \\
\text { waters }\end{array}$ \\
\hline $\begin{array}{l}\text { Impacts to migratory } \\
\text { birds }\end{array}$ & Migratory bird consultation & $\begin{array}{l}\text { Migratory Bird } \\
\text { Treaty Act }\end{array}$ & Fish and Wildlife Service & $\begin{array}{l}\text { Federal and state } \\
\text { waters, on shore }\end{array}$ \\
\hline Aquatic habitat alteration & $\begin{array}{l}\text { Fish and Wildlife Coordination } \\
\text { Act Consultation }\end{array}$ & $\begin{array}{l}\text { Fish and Wildlife } \\
\text { Coordination Act }\end{array}$ & USFWS (NMFS) & $\begin{array}{l}\text { Federal and state } \\
\text { waters }\end{array}$ \\
\hline $\begin{array}{l}\text { Consideration of } \\
\text { environmental impacts }\end{array}$ & $\begin{array}{l}\text { EA/EIS FONSI or ROD or } \\
\text { Categorical Exclusion }\end{array}$ & $\begin{array}{l}\text { National } \\
\text { Environmental } \\
\text { Policy Act }\end{array}$ & $\begin{array}{l}\text { USACE or NOAA (EPA, state } \\
\text { agencies, tribes) }\end{array}$ & $\begin{array}{l}\text { Federal and state } \\
\text { waters, on shore }\end{array}$ \\
\hline Water quality & $\begin{array}{l}\text { National Pollutant Discharge } \\
\text { Elimination System }\end{array}$ & $\begin{array}{l}\text { Clean Water Act } \\
\S 403 \text { (c) }\end{array}$ & Environmental Protection Agency & $\begin{array}{l}\text { Federal and state } \\
\text { waters, on shore }\end{array}$ \\
\hline
\end{tabular}




\begin{tabular}{|c|c|c|c|c|}
\hline Dredging and filling & CWA $§ 404$ Permit & Clean Water Act & USACE (EPA, USFWS, NMFS) & $\begin{array}{l}\text { Federal and state } \\
\text { waters, wetlands }\end{array}$ \\
\hline $\begin{array}{l}\text { Consistency of federal } \\
\text { action with state water } \\
\text { quality requirements }\end{array}$ & $\begin{array}{l}\text { CWA } \S 401 \text { Water Quality } \\
\text { Certification }\end{array}$ & Clean Water Act & Designated state agency & State waters \\
\hline $\begin{array}{l}\text { Consistency of federal } \\
\text { action with state Coastal } \\
\text { Management Program }\end{array}$ & $\begin{array}{l}\text { § } 307 \text { CZMA Federal } \\
\text { Consistency Determination }\end{array}$ & $\begin{array}{l}\text { Coastal Zone } \\
\text { Management Act }\end{array}$ & Designated state agency and NOAA & $\begin{array}{l}\text { Federal and state } \\
\text { waters }\end{array}$ \\
\hline $\begin{array}{l}\text { Preservation of historic } \\
\text { resources }\end{array}$ & $\S 106$ NHPA Consultation & $\begin{array}{l}\text { National Historic } \\
\text { Preservation Act }\end{array}$ & $\begin{array}{l}\text { Advisory Council on Historic } \\
\text { Preservation (USACE, state regulatory } \\
\text { agencies) }\end{array}$ & $\begin{array}{l}\text { Federal and state } \\
\text { waters, on shore }\end{array}$ \\
\hline $\begin{array}{l}\text { Navigational safety } \\
\text { (lights and signals) }\end{array}$ & $\begin{array}{l}\text { Private Aids to Navigation Permit } \\
\text { (PATON) }\end{array}$ & $\begin{array}{l}\S 407 \text { Rivers and } \\
\text { Harbors Act }\end{array}$ & $\begin{array}{l}\text { Coast Guard (USACE, state resource } \\
\text { agency) }\end{array}$ & $\begin{array}{l}\text { Federal and state } \\
\text { waters }\end{array}$ \\
\hline Navigational safety & USACE $\S 10$ Permit & $\begin{array}{l}\S 10 \text { Rivers and } \\
\text { Harbors Act of } \\
1899\end{array}$ & U.S. Army Corps of Engineers & $\begin{array}{l}\text { Federal and state } \\
\text { waters }\end{array}$ \\
\hline National security & DOD consultation & & Department of Defense & $\begin{array}{l}\text { Federal and state } \\
\text { waters }\end{array}$ \\
\hline Use of public lands & & $\begin{array}{l}\text { Outer Continental } \\
\text { Lands Act }\end{array}$ & $\begin{array}{l}\text { Army Corps of Engineers and } \\
\text { BOEMRE (USFWS, NOAA, USCG, } \\
\text { BIA, EPA, NPS, USFS, BLM, tribal } \\
\text { governments, state agencies) }\end{array}$ & Federal waters \\
\hline
\end{tabular}


For culture operations located in state waters, many state and county laws regulate development. State and local (county and city) permissions often include a permit to operate and a site lease plus permits for water quality and impacts to marine species and habitats. In addition to state and federal regulations, local zoning ordinances govern onshore facilities (i.e. greenhouses) and may apply to nearshore marine culture operations. Coastal zone consistency determinations ${ }^{10}$ made by states is also an important part of statelevel project review. A detailed list of state and local permits and regulatory actions for California, Massachusetts, and Maine are provided in Appendix A.

Various other federal statutes (Table 6) may have bearing on macroalgae aquaculture operations including section 27 of the Merchant Marine Act of 1920, also known as the Jones Act administered by the USCG, which requires hire of U.S. built and flagged vessels in U.S. waters; the Federal Insecticide, Fungicide, and Rodenticide Act administered by the EPA which regulates the use of chemical products; and the Food, Drug, and Cosmetic Act administered by the Food and Drug Administration (FDA), which regulates food and drug safety. A Clean Air Act permit may also be required for emissions from vessels associated with offshore culture operations. Projects proposed within or potentially affecting a National Marine Sanctuary would be reviewed by NOAA under the National Marine Sanctuaries Act and associated Sanctuary-specific management plans. The U.S. Department Agriculture also may have a consultation role in offshore macroalgae culture.

\footnotetext{
${ }^{10}$ Federal consistency is the CZMA requirement where federal agency activities that have reasonably foreseeable effects on any land or water use or natural resource of the coastal zone (also referred to as coastal uses or resources and coastal effects) must be consistent to the maximum extent practicable with the enforceable policies of a coastal state's federally approved coastal management program. For more information see http://coastalmanagement.noaa.gov/consistency/welcome.html.
} 


\section{V.SUMMARY}

Year 1 of the Macroalgae Analysis project focused on a preliminary feasibility analysis of macroalgae as a feedstock for biofuels production. Although the domestic commercial production of macroalgae in the U.S. is sufficiently low that it is not included in FAO production statistics (FAO, 2008), it was concluded in our FY2010 summary report that the resource potential for macroalgae production in U.S. marine waters was very high based on the worldwide rate of annual commercial production rate applied to the total area of the U.S. EEZ (Roesijadi et al., 2010). A science-based assessment of the resource in U.S. waters had yet to be conducted, and specific information on production potential needed for siting production facilities in U.S. waters was not available. Thus, we set as the goal for FY11 and out-years the development of a strategic analysis of potential U.S. macroalgae production. Such an assessment would require new GIS-based spatial analysis tools specific for analysis of macroalgal production potential in U.S. waters. These tools would be expected to expand current capabilities in assessing national biomass potential by including marine biomass as a new resource.

The efforts in FY11 on resource assessment, which initially focused on the development of analysis tools to increase current assessment capabilities, were accelerated so that the assessment framework could be applied to demonstration areas off the West and East Coasts of the U.S. EEZ. Models were developed to address two main topics: 1) Bio-physics-based macroalgal growth and production: define suitable environmental conditions for macroalgae growth and identify areas that would support macroalgal production and 2) Constraints analysis: conduct geospatial analysis and produce summary maps to provide an initial assessment of offshore cultivation opportunities and constraints, considering a limited number of competing ocean uses. A merger of the two models would be used to provide information on locating production facilities that would maximize production and minimize constraints. Additionally, reviews were completed for infrastructure needs and permitting requirements.

Application of the constraints model to the West and East Coast demonstration areas resulted in classification of constraints as low, moderate, and high, based on legal, environmental, and infrastructure considerations. Constraints modeling showed that there are fewer conflicts farther from shore and that, regionally, there are greater competing use conflicts in Southern California in comparison with the Gulf of Maine. Score Sensitivity, an analysis of the uncertainty of the level of constraint for individual metrics, can be used to develop predictions of differing levels of impact.

The development of suitability maps focused on two key variables driving macroalgal production: sea surface temperature and photosynthetically-active radiation. A broader level suitability screening was performed for the entire U.S. EEZ using these criteria. For the West Coast demonstration area, where the most progress was made, the model showed that production is impeded in the southern regions due to high temperature. When compared with the constraints modeling some locales further north and closer to the coastline where production is high would be highly constrained by conflicting activities.

Progress to date on resource assessment has culminated in a plan for a merged model that would combine the outputs of the Constraints Model and Macroalgae Growth Model, arranged hierarchically so that the identification of areas with high levels of constraints would limit where estimates for biomass production would need to be made. Progress in FY11 included assessment of the demonstration areas with numerical results for production to be limited by constraint class. The path forward includes refinement of the models and expansion of coverage from East Coast and West Coast model demonstration areas to the broader U.S. EEZ, thus providing a National Macroalgae Assessment. Completion of this work is contingent on future interest and needs of the Biomass Program. 
An assessment of infrastructure needs identified requirements for facilities for onshore cultivation and rearing of propagative stages, offshore deployment and rearing crops to harvestable stage, harvesting, and processing. Major information gaps that still need to be addressed were also identified. Large-scale macroalgae cultivation in the U.S. is still an emerging industry that has yet to be developed. The offshore marine environment presents unique challenges for installation of macroalgae cultivation facilities, and better definition of infrastructure needs will be possible as production facilities are deployed and tested. This will move forward as national policies for open ocean aquaculture, of which macroalgae are a subset, are developed and implemented. Permitting for both offshore and land-based activities to support macroalgae production and processing can be expected to involve multiple federal, state, and local laws that regulate development and industrial activities on land and in the marine environment. Locating marine aquaculture to offshore sites in the U.S. EEZ would shift the regulatory burden in marine waters to federal agencies. 


\section{FUTURE PROJECT RECOMMENDATIONS}

Continued work on the macroalgae growth model should focus on implementing and further testing the National Macroalgae Assessment Model. Using best available data, results would be expanded to determine optimal locations for macroalgae production across the U.S. EEZ. Potential macroalgae biomass growth and biofuel production would be estimated for locations congruent with those identified as suitable based on societal constraints.

Future efforts should also include an approach to assess national availability of land-based sites suitable for macroalgae infrastructure development based on current land use/ownership, distance considerations and supporting infrastructure needs and apply this approach nationally. This addition to the scope would enable inclusion of land-based considerations that would complement the models for macroalgae growth and competing uses and societal constraints in further refining site selection for macroalgae production.

The sites recommended by the National Macroalgae Assessment Model for siting cultivation activities would be assessed as a function of the needs and constraints for required infrastructure and competing uses of the water bodies. The results are expected to provide information for siting macroalgal farms, which takes into consideration the resource requirements that promote macroalgae production and the socio-political considerations that serve as constraints. The broader significance of this work is the development of a methodology for site assessment that would take into account the physical and societal perspectives of successful site determination for a new biomass resource.

\section{Relevance to Program Goals}

Meeting the EISA goal of increasing the supply of renewable and alternative fuels to 36 billion gallons per year by 2022 requires a reliable, sustainable, cost-competitive biomass supply. Biomass feedstocks are essential to achieving this goal, as they are the basis on which all other platforms rely. The goal of

providing 130 million dry tons per year of biomass by 2012 and 250 million dry tons per year by 2017 is supported by this work. 


\section{REFERENCES}

Aguilar-Manjarrez, J. and L. Ross (1995). Geographical Information System (GIS) Environmental Models for Aquaculture Development in Sinaloa State, Mexico. Aquaculture International(3): 103-115.

Aizawa, M., K. Asaoka, M. Atsumi and T. Sakou (2007). Seaweed bioethanol production in Japan - The Ocean Sunrise Project. Oceans 2007, Vancouver, Canada.

Anderson, N. (1974). A mathematical model for the growth of giant kelp. Simulation 22(4): 97-105.

Barr, S. (2010). Personal communication at Environmental Effects of Tidal Energy Development: A Scientific Workshop. G. Roesijadi. Seattle.

Bird, K. T. (1987). Cost analysis of energy from marine biomass. Seaweed Cultivation for Renewable Resources K. T. B. a. P. H. Benson. Amsterdam, Elsevier: 327-350.

Bird, K. T. and J. Benson (1987). Seaweed Cultivation for Renewable Resources. Amsterdam, Elsevier Science Ltd.

Bolton, J. J. and K. Luning (1982). Optimal-Growth and Maximal Survival Temperatures of Atlantic Laminaria Species (Phaeophyta) in Culture. Marine Biology 66(1): 89-94.

Buck, B. H. and C. M. Buchholz (2004). The offshore-ring: A new system design for the open ocean aquaculture of macroalgae. Journal of Applied Phycology 16(5): 355-368.

Buck, B. H., G. Krause and H. Rosenthal (2004). Extensive Open Ocean Aquaculture Development within Wind Farms in Germany: The prospect of Offshore Co-management and Legal Constraints. Ocean Coastal Management 47(3-4): 95-122.

Buck, H. B. and C. M. Buchholz (2005). Response of Offshore Cultivated Laminaria saccharina to Hydrodynamic Forcing in the North Sea. Aquaculture 250: 674-691.

Chynoweth, D. P., J. M. Owens and R. Legrand (2001). Renewable methane from anaerobic digestion of biomass. Renewable Energy 22(1-3): 1-8.

Dhanju, A., P. Whitaker and W. Kempton (2008). Assessing offshore wind resources: An accessible methodology. Renewable Energy 33(1): 55-64.

Dolmer, P. and K. Geitner (2004). Integrated Coastal Zone Management of Cultures and Fishery of Mussels in Limfjorden, Denmark. International Council for the Exploration of the Sea (ICES)(CM 2004/V:07): 9.

EERE Biomass Program (2011). Biomass Program Multi-Year Program Plan, April 2011. U.S. Department of Energy, Energy Efficiency and Renewable Energy.

FAO (2008). 2006 Fishery and Aquaculture Statistics. Rome, Food and Agriculture Organization of the United Nations.

FAO. (2011). Laminaria japonica. Cultured Species Information Programme: Aquaculture Fact Sheets: Cultured Aquatic Species, 2008.

Firestone, J., W. Kempton, A. Krueger and C. E. Loper (2004). Regulating Offshore Wind Power and Aquaculture: Messages from Land and Sea. Cornell Journal of Law and Public Policy 14(1).

Graham, M. H., B. P. Kinlan, L. D. Druehl, L. E. Garske and S. Banks (2007). Deep-water kelp refugia as potential hotspots of tropical marine diversity and productivity. Proceedings of the National Academy of Sciences of the United States of America 104(42): 16576-16580.

Gutierrez, A., T. Correa, V. Munoz, A. Santibanez, R. Marcos, C. Caceres and A. H. Buschmann (2006). Farming of the giant kelp Macrocystis pyrifera in southern Chile for development of novel food products. Journal of Applied Phycology 18(3-5): 259-267.

Hennenberg, K. J., U. Fritsche, R. Herrera, A. Eggert, M. Renato, S. Hunt and B. Bunnag (2009). Aquatic Biomass: Sustainable Bioenergy from Algae?,

Jaakson, R. (1971). Zoning to regulate on-water recreation. Land Economics 47: 382-388.

Jackson, G. A. (1987). Modeling the Growth and Harvest Yield of the Giant-Kelp Macrocystis-Pyrifera. Marine Biology 95(4): 611-624. 
Kapetsky, J. and J. Aguilar-Manjarrez (2007). Geographic Information Systems, Remote Sensing and Mapping for the Development and Management of Marine Aquaculture. Rome, Food and Agriculture Organization of the United Nations. http://www.fao.org/docrep/009/a0906e/a0906e00.htm.

Lisac, D. (1996). Recent developments in open sea cages - Pradtical experience with the Tension-Leg cage. Open Ocean Aquaculture, Proceedings of an International Conference, Portland, Maine.

Lisac, D. (1997). A tension leg cage for offshore aquaculture in the Mediterranean. Technology of Aquaculture in the Mediterranean (TECAM), Zaragoza Spain, CIHEAM Network

Longdill, P. C., T. R. Healy and K. P. Black (2008). An integrated GIS approach for sustainable aquaculture management area site selection. Ocean \& Coastal Management 51(8-9): 612-624.

Loverich, G. and C. Goudey (1996). Design and Operation of an Offshore Sea Farming System. Open Ocean Aquaculture, Portland Maine.

Macchiavello, J., E. Araya and C. Bulboa (2010). Production of Macrocystis pyrifera (Laminariales; Phaeophyceae) in northern Chile on spore-based culture. Journal of Applied Phycology 22: 691697.

Macleod, M. (2007). Potential Offshore Aquaculture Siting off Massachusetts: A Geographic Information Systems (GIS) analysis using the examples of Cod (Gadhus morhua) and Mussels (Mytilus edulis). Environmental Studies, Brown University. MA: 95.

Malczewski, J. (1999). GIS and Multicriteria Decision Analysis, John Wiley and Sons, Inc.

Martins, I. and J. C. Marques (2002). A model for the growth of opportunistic macroalgae (Enteromorpha sp.) in tidal estuaries. Estuarine Coastal and Shelf Science 55(2): 247-257.

Minnett, P. J. and B. Ward (2000). Measurements Of Near-Surface Ocean Temperature Variability -Consequences On The Validation Of Aatsr On Envisat. CiteSeerX.

Molina-Ruiz, J., M. J. Martinez-Sanchez, C. Perez-Sirvent, M. L. Tudela-Serrano and M. L. G. Lorenzo (2011). Developing and applying a GIS-assisted approach to evaluate visual impact in wind farms. Renewable Energy 36(3): 1125-1132.

Nath, S. S., J. P. Bolte, L. G. Ross and J. Aguilar-Manjarrez (2000). Applications of geographical information systems (GIS) for spatial decision support in aquaculture. Aquacultural Engineering 23(1-3): 233-278.

Nobre, A., M. Pacheco, R. Jorge, M. F. P. Lopes and L. M. C. Gato (2009). Geo-spatial multi-criteria analysis for wave energy conversion system deployment. Renewable Energy 34(1): 97-111.

North, W. J. (1987). Oceanic farming of Macrocystis, the problems and non-problems. Seaweed Cultivation for Renewable Resources K. T. B. a. P. H. Benson. Amsterdam, Elsevier: 39-67.

NZRAC, N. Z. b. t. A. R. C. (2002). Factors related to the sustainability of shellfish aquaculture operations in the Firth of Thames: a prelimiary analysis. Auckland Regional Council, Auckland Regional Council. 182.

Pacific Energy Ventures (2010). Siting methodologies for hydrokinetics: Navigating the regulatory framework., Pacific Energy Ventures LLC on behalf of the U.S. Department of Energy. http://www.advancedh2opower.com/default.aspx.

Perez, O. M., T. C. Telfer and L. G. Ross (2003). Use of GIS-Based Models for Integrating and Developing Marine Fish Cages within the Tourism Industry in Tenerife (Canary Islands). Coastal Management 31(4): 355-366(312).

Petrell, R. J., K. M. Tabrizi, P. J. Harrison and L. D. Druehl (1993). Mathematical-model of Laminaria production near a British-Columbian salmon sea cage farm. Journal of Applied Phycology 5(1): $1-14$.

Pew Oceans Commission (2003). Guiding Sustainable Marine Aquaculture. America's Living Oceans: Charting a Course for Sea Change. A Report to the Nation. Chapter 14. Washington, D.C.

Radiarta, N., S. I. Saitoh and A. Miyazono (2008). GIS-based multi-criteria evaluation models for identifying suitable sites for Japanese scallop (Mizuhopecten yessoensis) aquaculture in Funka Bay, southwestern Hokkaido, Japan. Aquaculture 284(1-4): 127-135. 
Roesijadi, G., A. E. Copping, M. H. Huesemann, J. Forster and J. R. Benemann (2008). TechnoEconomic Feasibility Analysis of Offshore Seaweed Farming for Bioenergy and Biobased Products, Battelle Pacific Northwest Division Report Number PNWD-3931.

Roesijadi, G., S. B. Jones, L. J. Snowden-Swan and Y. Zhu (2010). Macroalgae as a biomass feedstock: a preliminary analysis. Pacific Northwest National Laboratory.

Salam, M. (2003). A comparison of development opportunities for crab and shrimp aquaculture in southwestern Bangladesh, using GIS modelling. Aquaculture 220(1-4): 477-494.

Tetra Tech EC, I., A. O. Solutions, C. E. Corporation, D. a. A. E. Strategies, F. Associates, T. G. Associates and M. A. International (2010). Port and Infrastructure Analysis for Offshore Wind Energy Development. Boston, Tetra Tech EC, Inc.

U.S. Commission on Ocean Policy (2004). Setting a Course for Sustainable Marine Aquaculture. An Ocean Blueprint for the 21st Century. Final Report. Chapter 22. Washington, D.C.

Ugarte, R. and G. Sharp (2001). A new approach to seaweed management in Eastern Canada:the case of Ascophyllum nodosum. Cahiers de Biologie Marine 42: 63-70.

Upton, H. F. and E. H. Buck (2010). Open Ocean Aquaculture. http://cnie.org/NLE/CRSreports/10Sep/RL32694.pdf.

van Haaren, R. and V. Fthenakis (2011). GIS-based wind farm site selection using spatial multi-criteria analysis (SMCA): Evaluating the case for New York State. Renewable and Sustainable Energy Reviews 15(7): 3332-3340.

Wahle, C., D’Lorio and N. Hayden (2009). California Ocean Uses Atlas Project.

Wigmosta, M. S., A. M. Coleman, R. J. Skaggs, M. H. Huesemann and L. J. Lane (2011). National microalgae biofuel production potential and resource demand. Water Resources Research 47(W00H04): 13.

Yokoyama, S., K. Jonouchi and K. Imou (2007). Energy Production from Marine Biomass: Fuel Cell Power Generation Driven by Methane Produced from Seaweed. World Academy of Science, Engineering and Technology 28: 320-323. 


\section{APPENDIX A: SUMMARY OF STATE AND LOCAL AUTHORIZATIONS FOR CALIFORNIA, MAINE, AND MASSACHUSETTS}

Table A. Summary of California Authorizations including federal authorizations delegated to states. (Pacific Energy Ventures, 2010).

\begin{tabular}{|c|c|c|c|}
\hline $\begin{array}{c}\text { Authorization/ } \\
\text { Review }\end{array}$ & $\begin{array}{l}\text { Primary Legal } \\
\text { Authority }\end{array}$ & Lead Agency & Process Time \\
\hline $\begin{array}{l}\S 401 \text { Water Quality } \\
\text { Certification }\end{array}$ & $\begin{array}{l}\text { Clean Water Act } \S 401 \text {; } \\
\text { CAL. CODE REGS. tit. 23, } \\
\S 3.28\end{array}$ & $\begin{array}{l}\text { State or Regional } \\
\text { Water Quality Control } \\
\text { Board }\end{array}$ & Up to one year \\
\hline $\begin{array}{l}\text { CZMA Federal } \\
\text { Consistency } \\
\text { Determination }\end{array}$ & $\begin{array}{l}\text { Coastal Zone } \\
\text { Management Act } \S 307\end{array}$ & $\begin{array}{l}\text { California Coastal } \\
\text { Commission }\end{array}$ & $\begin{array}{l}\text { Up to six months } \\
\text { from receipt of } \\
\text { complete } \\
\text { application }\end{array}$ \\
\hline $\begin{array}{l}\text { Coastal Development } \\
\text { Permit }\end{array}$ & $\begin{array}{l}\text { California Coastal Act, } \\
\text { PUB. RES. CODE } \S 30000 \\
\text { et seq. }\end{array}$ & $\begin{array}{l}\text { California Coastal } \\
\text { Commission and/or } \\
\text { Local Government }\end{array}$ & Varies \\
\hline $\begin{array}{l}\text { California Environmental } \\
\text { Quality Act Declaration }\end{array}$ & $\begin{array}{l}\text { California } \\
\text { Environmental Quality } \\
\text { Act, PUB. RES. CODE } \S \\
21000 \text { et seq. }\end{array}$ & \multirow[t]{2}{*}{$\begin{array}{l}\text { State Lands } \\
\text { Commission }\end{array}$} & $\begin{array}{l}\text { Up to one year for } \\
\text { EIR }{ }^{1} \text {; up to } 105 \text { days } \\
\text { for Negative } \\
\text { Declaration* }\end{array}$ \\
\hline State Tidelands Lease & $\begin{array}{l}\text { California Public } \\
\text { Resources Code }\end{array}$ & & Varies \\
\hline $\begin{array}{l}\text { California Endangered } \\
\text { Species Consultation }\end{array}$ & $\begin{array}{l}\text { California Endangered } \\
\text { Species Act }\end{array}$ & $\begin{array}{l}\text { Department of Fish } \\
\text { and Game, Habitat } \\
\text { Conservation Planning } \\
\text { Branch }\end{array}$ & Varies \\
\hline
\end{tabular}

(1) Environmental Impact Report 
Table B. Summary of Maine Authorizations including federal authorizations delegated to states (Pacific Energy Ventures, 2010).

\begin{tabular}{|c|c|c|c|}
\hline Authorization/Review & Primary Legal Authority & Lead Agency & $\begin{array}{l}\text { Anticipated } \\
\text { Process Time }\end{array}$ \\
\hline $\begin{array}{l}\text { Maine Waterway } \\
\text { Development \& } \\
\text { Conservation Act Permit }\end{array}$ & $\begin{array}{l}\text { Maine Waterway } \\
\text { Development \& } \\
\text { Conservation Act }\end{array}$ & $\begin{array}{l}\text { Dept. of Environmental } \\
\text { Protection or Land Use } \\
\text { Regulation Commission }\end{array}$ & Up to 12 months \\
\hline $\begin{array}{l}\text { Maine Endangered Species } \\
\text { Act Review }\end{array}$ & $\begin{array}{l}\text { Maine Endangered Species } \\
\text { Act }\end{array}$ & $\begin{array}{l}\text { Dept. of Marine } \\
\text { Resources \&/or Dept. of } \\
\text { Inland Fisheries \& } \\
\text { Wildlife }\end{array}$ & $4 \frac{1}{2}$ months \\
\hline $\begin{array}{l}\S 401 \text { Water Quality } \\
\text { Certification }\end{array}$ & $\begin{array}{l}\text { Federal Clean Water Act } \S \S \\
401\end{array}$ & $\begin{array}{l}\text { Dept. of Environmental } \\
\text { Protection or Land Use } \\
\text { Regulation Commission }\end{array}$ & Up to one year \\
\hline $\begin{array}{l}\text { CZMA }^{1} \text { Federal Consistency } \\
\text { Determination }\end{array}$ & $\begin{array}{l}\text { Coastal Zone Management } \\
\text { Act, Coastal Management } \\
\text { Policies Act }\end{array}$ & State Planning Office & Up to 6 months \\
\hline Submerged Lands Lease & $\begin{array}{l}\text { Submerged Lands Law } \\
12 \text { M.R.S.A. §§ 1861-1867 }\end{array}$ & $\begin{array}{l}\text { Dept. of Conservation, } \\
\text { Bureau of Public Lands }\end{array}$ & 2 months \\
\hline Historic Review & 27 M.R.S.A. §§ 501-503 & $\begin{array}{l}\text { Maine Historical } \\
\text { Preservation } \\
\text { Commission } \\
\end{array}$ & 3 months \\
\hline $\begin{array}{l}\text { Mandatory Shoreland } \\
\text { Zoning Act Permit }\end{array}$ & $\begin{array}{l}\text { Mandatory Shoreland } \\
\text { Zoning Act } \\
38 \text { M.R.S.A. §§ } 435-449\end{array}$ & Municipality, DEP ${ }^{2}$ & $\begin{array}{l}35 \text { Working Days } \\
\text { from receipt of } \\
\text { complete } \\
\text { application }\end{array}$ \\
\hline
\end{tabular}

(1) Coastal Zone Management Act

(2) Department of Environmental Protection 
Table C. Summary of Massachusetts Authorizations including federal authorizations delegated to states (Pacific Energy Ventures, 2010).

\begin{tabular}{|c|c|c|c|}
\hline Authorization/Review & Primary Legal Authority & Lead Agency & $\begin{array}{l}\text { Anticipated } \\
\text { Process Time }\end{array}$ \\
\hline $\begin{array}{l}\text { Massachusetts } \\
\text { Environmental Policy Act } \\
\text { Certificate }\end{array}$ & $\begin{array}{l}\text { Massachusetts } \\
\text { Environmental Policy Act }\end{array}$ & $\begin{array}{l}\text { Mass. Environmental } \\
\text { Policy Act Unit }\end{array}$ & $\begin{array}{l}\text { Varies; generally, } \\
\text { at least one year }\end{array}$ \\
\hline $\begin{array}{l}\text { Massachusetts Endangered } \\
\text { Species } \\
\text { Act Review }\end{array}$ & $\begin{array}{l}\text { Massachusetts Endangered } \\
\text { Species Act }\end{array}$ & $\begin{array}{l}\text { Natural Heritage \& } \\
\text { Endangered Species } \\
\text { Program }\end{array}$ & $\begin{array}{l}\text { One month from } \\
\text { receipt of } \\
\text { complete Request }\end{array}$ \\
\hline Order of Conditions & $\begin{array}{l}\text { Massachusetts Wetlands } \\
\text { Protection Act }\end{array}$ & $\begin{array}{l}\text { Local Conservation } \\
\text { Commission \& DEP }{ }^{1} \text { - } \\
\text { Wetlands \& Waterways } \\
\text { Program }\end{array}$ & $\begin{array}{l}\text { One month from } \\
\text { receipt of } \\
\text { complete } \\
\text { application }\end{array}$ \\
\hline $\begin{array}{l}\S 401 \text { Water Quality } \\
\text { Certification }\end{array}$ & $\begin{array}{l}\text { MA Clean Water Act; Surface } \\
\text { Water Quality Standards; } \\
\text { CWA § } 401\end{array}$ & $\begin{array}{l}\text { DEP- Wetlands \& } \\
\text { Waterways Program }\end{array}$ & Up to one year \\
\hline $\begin{array}{l}\text { State Fisheries } \\
\text { Recommendations }\end{array}$ & $\begin{array}{l}\text { M.G.L. c. } 21, \S 5 \text {, and c. } 130 \text {, } \\
\S \S 1-104: \text { Marine Fisheries; } \\
322 \text { CMR } 2.00 \text { et seq.: Marine } \\
\text { Fisheries Regulations. }\end{array}$ & $\begin{array}{l}\text { DEP \& Division of } \\
\text { Marine Fisheries }\end{array}$ & Up to 12 months 1 \\
\hline $\begin{array}{l}\text { Chapter } 91 \text { Waterways } \\
\text { License or Permit }\end{array}$ & $\begin{array}{l}\text { M.G.L c. } 91 \text { Public Waterfront } \\
\text { Act; } 310 \text { CMR } 9.00 \text { Waterway } \\
\text { Regulations }\end{array}$ & $\begin{array}{l}\text { DEP- Wetlands \& } \\
\text { Waterways Program }\end{array}$ & $\begin{array}{l}\text { At least } 3 \text { to } 6 \\
\text { months from } \\
\text { receipt of } \\
\text { complete } \\
\text { application }\end{array}$ \\
\hline $\begin{array}{l}\text { CZMA }^{2} \text { Federal Consistency } \\
\text { Determination }\end{array}$ & $\begin{array}{l}\text { CZMA Section } 307 \text {; } \\
\text { Massachusetts Coastal Zone } \\
\text { Management Act }\end{array}$ & $\begin{array}{l}\text { MA Office of Coastal } \\
\text { Zone Management }\end{array}$ & Up to 6 months \\
\hline $\begin{array}{l}\text { Underwater Archeological } \\
\text { Survey Permit }\end{array}$ & $\begin{array}{l}\text { M.G.L. c. 6, §§ } 179 \text { \& 180: } \\
312 \text { CMR 2.00: }\end{array}$ & $\begin{array}{l}\text { Board of Underwater } \\
\text { Archeological } \\
\text { Resources }\end{array}$ & One week \\
\hline Historic Properties Review & Historic District Act & MA & $\begin{array}{l}\text { At least two } \\
\text { months }\end{array}$ \\
\hline
\end{tabular}

(1) Mass. Department of Environmental Protection

(2) Coastal Zone Management Act 


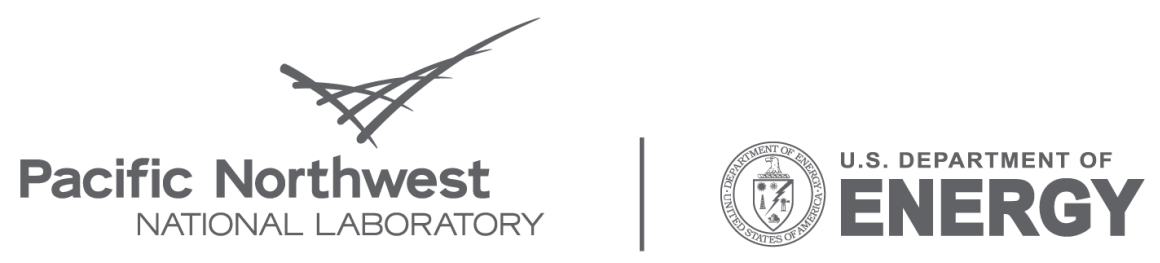

Proudly Operated by Battelle Since 1965

902 Battelle Boulevard

P.O. Box 999

Richland, WA 99352

1-888-375-PNNL (7665)

www.pnl.gov 